\title{
Anti-Cancer Agents in Proliferation and Cell Death: The Calcium Connection
}

\author{
Elizabeth Varghese ${ }^{1}$, Samson Mathews Samuel ${ }^{1} \mathbb{D}$, Zuhair Sadiq $^{1} \mathbb{D}$, Peter Kubatka $^{2} \mathbb{D}$,
} Alena Liskova ${ }^{3}$, Jozef Benacka ${ }^{4}$, Peter Pazinka ${ }^{5}$, Peter Kruzliak ${ }^{6,7}$ and Dietrich Büsselberg ${ }^{1, *(1)}$

1 Department of Physiology and Biophysics, Weill Cornell Medicine-Qatar, Education City, Qatar Foundation, Doha P.O. Box 24144, Qatar; elv2007@qatar-med.cornell.edu (E.V.); sms2016@qatar-med.cornell.edu (S.M.S.); zuhairsadiq2018@u.northwestern.edu (Z.S.)

2 Department of Medical Biology and Department of Experimental Carcinogenesis, Division of Oncology, Biomedical Center Martin, Jessenius Faculty of Medicine, Comenius University in Bratislava, 03601 Martin, Slovakia; kubatka@jfmed.uniba.sk

3 Department of Obstetrics and Gynecology, Jessenius Faculty of Medicine, Comenius University in Bratislava, 03601 Martin, Slovakia; alenka.liskova@gmail.com

4 Faculty Health and Social Work, Trnava University, 91843 Trnava, Slovakia; jozef.benacka@centrum.cz

5 Department of Surgery, Faculty of Medicine, Pavol Jozef Safarik University and Louise Pasteur University Hospital, 04022 Kosice, Slovakia; peter.pazinka@seznam.cz

6 Department of Internal Medicine, Brothers of Mercy Hospital, Polni 553/3, 63900 Brno, Czech Republic; peter.kruzliak@savba.sk

7 2nd Department of Surgery, Faculty of Medicine, Masaryk University and St. Anne's University Hospital, 65692 Brno, Czech Republic

* Correspondence: dib2015@qatar-med.cornell.edu; Tel.: +974-4492-8334

Received: 7 May 2019; Accepted: 14 June 2019; Published: 20 June 2019

Abstract: Calcium $\left(\mathrm{Ca}^{2+}\right)$ signaling and the modulation of intracellular calcium $\left(\left[\mathrm{Ca}^{2+}\right]_{\mathrm{i}}\right)$ levels play critical roles in several key processes that regulate cellular survival, growth, differentiation, metabolism, and death in normal cells. On the other hand, aberrant $\mathrm{Ca}^{2+}$-signaling and loss of $\left[\mathrm{Ca}^{2+}\right]_{i}$ homeostasis contributes to tumor initiation proliferation, angiogenesis, and other key processes that support tumor progression in several different cancers. Currently, chemically and functionally distinct drugs are used as chemotherapeutic agents in the treatment and management of cancer among which certain anti-cancer drugs reportedly suppress pro-survival signals and activate pro-apoptotic signaling through modulation of $\mathrm{Ca}^{2+}$-signaling-dependent mechanisms. Most importantly, the modulation of $\left[\mathrm{Ca}^{2+}\right]_{i}$ levels via the endoplasmic reticulum-mitochondrial axis and corresponding action of channels and pumps within the plasma membrane play an important role in the survival and death of cancer cells. The endoplasmic reticulum-mitochondrial axis is of prime importance when considering $\mathrm{Ca}^{2+}$-signaling-dependent anti-cancer drug targets. This review discusses how calcium signaling is targeted by anti-cancer drugs and highlights the role of calcium signaling in epigenetic modification and the Warburg effect in tumorigenesis.

Keywords: Intracellular calcium; anti-cancer drugs; apoptosis; proliferation

\section{Intracellular Calcium Homeostasis and Calcium Signaling}

Intracellular calcium $\left(\left[\mathrm{Ca}^{2+}\right]_{\mathrm{i}}\right)$ is an important second messenger involved in cellular functions of muscles, neurons, immune cells, oocytes and others, modulating enzyme secretion, gene activation, proliferation, apoptosis, cell cycle progression, fertilization, and release of neurotransmitters [1-3]. Aberrant $\left[\mathrm{Ca}^{2+}\right]_{\mathrm{i}}$-signaling has been implicated in diseases such as Alzheimer's, cancer, congestive 
heart failure, and diabetes [4-6]. In cancer, $\left[\mathrm{Ca}^{2+}\right]_{\mathrm{i}}$-signaling is involved in various processes of tumorigenesis such as proliferation, migration, angiogenesis, and evasion of apoptosis $[7,8]$.

The concentration of $\mathrm{Ca}^{2+}$ in different compartments of a cell differs greatly $\left(\left[\mathrm{Ca}^{2+}\right]_{\mathrm{i}}: 100 \mathrm{nM}\right.$; extracellular calcium $\left[\mathrm{Ca}^{2+}\right]_{0}: 1-1.5 \mathrm{mM}$; in the endoplasmic reticulum (ER): $0.5-1 \mathrm{mM}$; in the mitochondria: 100-200 $\mathrm{nM}$ (but can accumulate 10-20 fold upon activation) [9]. [ $\left.\mathrm{Ca}^{2+}\right]_{\mathrm{i}}$ is tightly maintained at a low concentration by numerous regulating mechanisms, that include both active and passive mechanisms, e.g., channels or pumps on the plasma membrane, ER, mitochondria, and cytosol (Figure 1) [10-13]. In addition to channels and pumps, $\left[\mathrm{Ca}^{2+}\right]_{\mathrm{i}}$ is modulated by a heterogeneous group of calcium binding proteins (CBP), including S100 proteins, calmodulin, and calcineurin. Binding of $\mathrm{Ca}^{2+}$ with CBP regulates signal transduction and gene expression [14]. Undoubtedly, the nucleus acts as a major compartment in which $\mathrm{Ca}^{2+}$ is sequestered. Nuclear $\mathrm{Ca}^{2+}$ has specific biological functions involved in gene expression and regulation [15]. The involvement of the nucleus in $\left[\mathrm{Ca}^{2+}\right]_{\mathrm{i}}$-regulation and its role in cell proliferation is extensively reviewed by Resende and colleagues [16]. Importantly, some studies proposed nuclear calcium signaling as an independent entity producing localized calcium-signaling and triggering the transcription of genes related to cell proliferation [17]. On the contrary, it is reported that nuclear $\left[\mathrm{Ca}^{2+}\right]$ is dependent on changes in $\left[\mathrm{Ca}^{2+}\right]_{\mathrm{i}}[18,19]$.

$\left[\mathrm{Ca}^{2+}\right]_{\mathrm{i}}$-signaling is initiated by the entry of $\mathrm{Ca}^{2+}$ from an extracellular pool or by releasing $\mathrm{Ca}^{2+}$ from ER stores or mitochondria. This increases $\left[\mathrm{Ca}^{2+}\right]_{\mathrm{i}}$ from $100 \mathrm{nM}$ (at rest) to approximately $1000 \mathrm{nM}$ generating an "ON" signal for multiple processes. As a prolonged increase in $\left[\mathrm{Ca}^{2+}\right]_{\mathrm{i}}$ may be harmful, the $\left[\mathrm{Ca}^{2+}\right]_{i}$ signals are spatially and temporally regulated [7]. Calcium binding proteins $\left(\mathrm{Ca}^{2+} /\right.$ calmodulin-dependent protein kinase II (CAMKII) and protein kinase C) decode the $\mathrm{Ca}^{2+}$ signals to various cellular processes $[20,21]$. With the completion of the cellular responses, an "OFF" mechanism restores the low concentration of $\left[\mathrm{Ca}^{2+}\right]_{\mathrm{i}} \cdot\left[\mathrm{Ca}^{2+}\right]_{\mathrm{i}}$-signaling is involved in both proliferation and apoptosis. $\mathrm{Ca}^{2+}$-oscillations stimulate cell proliferation via $\mathrm{Ca}^{2+}$ sensitive transcription factor (NFAT) and conversely, an increase in $\left[\mathrm{Ca}^{2+}\right]_{\mathrm{i}}$ for a longer duration activates apoptosis [22].

Abnormalities in $\left[\mathrm{Ca}^{2+}\right]_{\mathrm{i}}$-signaling are associated with various cancers and is also implicated in therapy resistance [23-25]. An extensive review by Cui et al. broadly outlines calcium regulating proteins altered in specific cancer types and enlist those compounds targeting calcium-signaling [7]. In this review we analyze the anti-cancer action of selected agents targeting the calcium dependent pathways regulating proliferation and apoptosis. Here, we emphasize the role of calcium-signaling in proliferation and apoptosis and in addition, highlight calcium dependent modification of tumor energy metabolism and epigenetic modification of genes by anti-cancer agents.

\section{2. $\left[\mathrm{Ca}^{2+}\right]_{\mathrm{i}}$-Signaling in Cell Proliferation and Apoptosis}

$\left[\mathrm{Ca}^{2+}\right]_{\mathrm{i}}$ is a versatile second messenger in both proliferation and cell death. $\left[\mathrm{Ca}^{2+}\right]_{\mathrm{i}}$-signaling involves the participation of various proteins combined differently depending upon the type of cellular process initiated (Figure 1). $\left[\mathrm{Ca}^{2+}\right]_{i}$-signaling is spatially and temporally distinct for proliferation or apoptosis [26]. Transition of a normal cell to malignant cell involves altered function, translation, and expression of various proteins involved in the calcium regulation and signaling. Therefore, aberrant regulation of $\left[\mathrm{Ca}^{2+}\right]_{\mathrm{i}}$ levels may lead to uncontrolled proliferation and inhibition of apoptosis and thus contribute to carcinogenesis [27].

\section{1. $\left[\mathrm{Ca}^{2+}\right]_{i}$-Signaling and Cell Proliferation}

$\left[\mathrm{Ca}^{2+}\right]_{\mathrm{i}}$-signaling mediated by the channels on the plasma membrane and by exchange of $\mathrm{Ca}^{2+}$ between the spatially and temporally separated ER and mitochondria determines the type of down-stream signaling which will be activated. The following section focuses on the association between proliferation and extracellular calcium and the influence of $\mathrm{Ca}^{2+}$-channels on proliferation. We will also discuss store-operated calcium entry, the sarco/endoplasmic reticulum calcium ATPase (SERCA), and the ER and mitochondrial axis in proliferation. 


\section{2. $\left[\mathrm{Ca}^{2+}\right]_{0}$ in Cell Proliferation}

Extracellular calcium $\left(\left[\mathrm{Ca}^{2+}\right]_{\mathrm{o}}\right)$ modulates various cellular processes via calcium channels and extracellular calcium-sensing G-protein coupled receptors, which include calcium-sensing receptor (CaSR) and GPRC6a [21]. Past studies describe $\left[\mathrm{Ca}^{2+}\right]_{o}$ as a key regulator of proliferation in chicken fibroblast [28]. A significant difference in the proliferation rate of normal vs. transformed chicken fibroblast is associated with changes of $\left[\mathrm{Ca}^{2+}\right]_{0}$. Similar observations were made in mouse 3T3 cells, with cell proliferation being dependent on $\left[\mathrm{Ca}^{2+}\right]_{0}$, while a calcium driven mechanism initiated DNA synthesis and cell cycle progression that ultimately resulted in cell division [29,30]. Moreover, the influence of $\left[\mathrm{Ca}^{2+}\right]_{o}$ and its role in proliferation is reviewed in detail by Borowiec [30], emphasizing that $\left[\mathrm{Ca}^{2+}\right]_{\mathrm{o}}$ potentially exerts biological actions via sensor proteins on the plasma membrane. CaSR senses $\left[\mathrm{Ca}^{2+}\right]_{\mathrm{o}}$ and thus triggers the influx of $\mathrm{Ca}^{2+}$ through specific channels and regulates $\mathrm{Ca}^{2+}$ absorption and homeostasis in various organs. A reduction of $\mathrm{Ca}^{2+}$ influx by blocking calcium channels at the plasma membrane (PM) or reduction of $\left[\mathrm{Ca}^{2+}\right]_{0}$ attenuates cell proliferation [31].

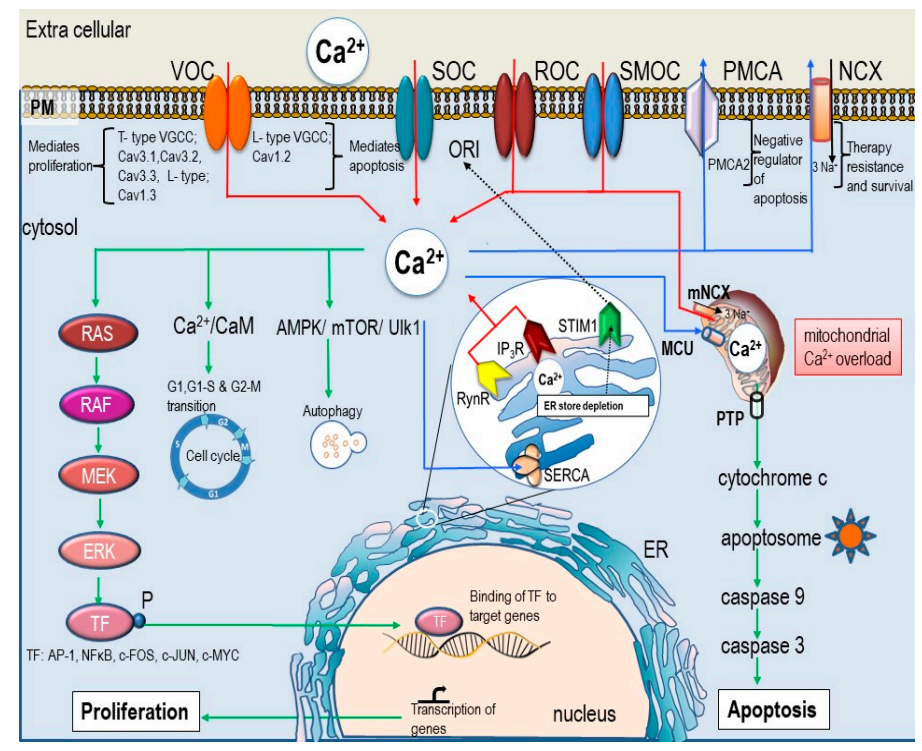

Figure 1. $\mathrm{Ca}^{2+}$-signaling in proliferation and apoptosis. $\left[\mathrm{Ca}^{2+}\right]_{\mathrm{i}}$ homeostasis of the cell is strictly regulated by various channels and pumps on plasma membrane, ER, and mitochondria. Intracellular calcium flux is indicated by arrows where red arrows indicate influx of $\mathrm{Ca}^{2+}$ ions, blue arrows indicate $\mathrm{Ca}^{2+}$ efflux and sequestration of $\mathrm{Ca}^{2+}$ into the stores, and green arrows indicate cell signaling pathways which are activated by $\left[\mathrm{Ca}^{2+}\right]_{\text {i }}$. Primarily $\mathrm{Ca}^{2+}$ influx from the extra-cellular space is controlled by VOC (voltage operated calcium channel), SOC (store-operated Orai channels), SMOC (second messenger-operated channel), or ROC (receptor-operated channel), and $\mathrm{Ca}^{2+}$ efflux is mediated via (NCX $\left(\mathrm{Na}^{+} / \mathrm{Ca}^{2+}\right.$ exchanger) and PMCA (plasma membrane $\mathrm{Ca}^{2+}$-ATPase). $\mathrm{Ca}^{2+}$ release from the ER stores is facilitated via RyR (ryanodine receptors) and $\mathrm{IP}_{3} \mathrm{R}\left(\mathrm{IP}_{3}\right.$ receptor). Uptake of calcium from the cytosol is an energy driven process mediated by SERCA (sarcoplasmic/ER Ca ${ }^{2+}$-ATPase). Additionally, mitochondria and associated proteins (including mitochondrial calcium uniporter (MCU), voltage dependent anion channel (VDAC), and mitochondrial $\mathrm{Na}^{+} / \mathrm{Ca}^{2+}$ exchanger (mNCX) are also related to $\left[\mathrm{Ca}^{2+}\right]_{\mathrm{i}}$-regulation. Mitochondrial- $\mathrm{Ca}^{2+}$ controls ATP synthesis, apoptosis, ROS generation, and biosynthesis and can determine the fate of the cell. The concentration of $\mathrm{Ca}^{2+}$ in the cytosol is maintained at a low level $(100 \mathrm{nM})$ in comparison to the extra cellular $\mathrm{Ca}^{2+}(1 \mathrm{mM})$. Any change in the $\left[\mathrm{Ca}^{2+}\right]_{\mathrm{i}}$ results in signal transduction initiating various cellular process such as apoptosis, proliferation, and cell division. The type of signal depends on the duration, amplitude, localization, frequency, and oscillation. Sustained high level of $\mathrm{Ca}^{2+}$ in the mitochondria causes the release of cytochrome $c$ and subsequently triggers death signals via caspase activation. More $\mathrm{Ca}^{2+}$ influx from the ion channels on the plasma membrane can trigger either proliferation (via T-type) or apoptosis (via L-type). Increased $\mathrm{Ca}^{2+}$ entry through the SOC channel promotes proliferation [32]. 


\subsection{Role of $\mathrm{Ca}^{2+}$ Channels and Pumps in Proliferation}

Ion channels are characterized as protein microchannels regulating intracellular concentrations of ions, contributing to the signaling pathways and influencing the overall behavior of cells [33]. Calcium selective channels are abundantly expressed on the plasma membrane which regulates $\mathrm{Ca}^{2+}$-influx. Voltage-gated calcium channels (VGCCs) (also known as voltage operated channels (VOC) (see Figures 1 and 2) sense the depolarization of membrane potentials and open their calcium-selective channel pore, allowing $\mathrm{Ca}^{2+}$ entry into the cell, thus contributing to physiological processes [33,34]. Based on their electrophysiological properties, VGCCs are classified into 5 groups: L-type $\left(\mathrm{Ca}_{\mathrm{v}} 1\right)$, T-type $\left(\mathrm{Ca}_{\mathrm{v}} 3\right)$, N-type $\left(\mathrm{Ca}_{\mathrm{v}} 2\right)$, P-type $\left(\mathrm{Ca}_{\mathrm{v}} 2\right)$, and R-type $\left(\mathrm{Ca}_{\mathrm{v}} 2\right)$. In non-excitable cells, VGCCs [33] are associated with the regulation of cell proliferation and apoptosis [35]. Aberrant function of VGCCs is related to the progression of different malignancies. Phan et al., in their review, discuss altered VGCC family genes and its link to 19 different cancer types including brain, kidney, breast, and lung cancers [34]. It highlights the downregulation of specific VGCC family-genes in different cancers and emphasizes their role as tumor suppressor genes. Among the different VGCCs, L-type channels show a strong association with proliferation and migration of cancer cells. Moreover, estrogen can modulate the expression of ion channels. A higher expression of L-type channels $\left(\mathrm{Ca}_{\mathrm{v}} 1.3\right)$ correlates with an increase in $17 \beta$-estradiol level in endometrial cancer (EC). The mechanism behind $\mathrm{Ca}^{2+}$-induced cell proliferation involves the interaction of estrogen binding to G-protein coupled estrogen receptor (GPER) causing the L-type channel to open and allow $\mathrm{Ca}^{2+}$-entry, followed by downstream activation of the ERK1/2-CREB pathway promoting cell proliferation. L-type channels are also involved in migration of EC cells [35,36]. Additionally, a high level of estrogen is associated with increased breast cancer $(\mathrm{BC})$ risk. The mechanism of estrogen-BC risk is linked to a pathway similar to EC proliferation. Importantly, estrogen induced a dose-dependent increase in the expression of $\mathrm{Ca}_{\mathrm{v}} 1.3$ in MCF-7 cells. The silencing of G protein-coupled estrogen receptor 30 (GPER1/GPR30) mediated via siRNA transfection abolished $\mathrm{Ca}^{2+}$-influx as well as proliferation in $\mathrm{BC}$, which may be an indication of a crucial role of $\mathrm{Ca}^{2+}$ entry through L-type channels in cell proliferation and breast cancer progression [29]. Furthermore, overexpression of the Calcium voltage-gated channel subunit alpha1 D gene (CACNA1D) is associated with prostate cancer progression. Importantly, $\left[\mathrm{Ca}^{2+}\right]_{i}$ measurements showed that an androgen stimulated $\mathrm{Ca}^{2+}$ influx was sensitive to nifedipine, indicating that L-type calcium channels were responsible for the androgen-stimulated $\mathrm{Ca}^{2+}$-influx in LNCaP cells. Interestingly, blocking of L-type channels resulted in decreased cell growth [37].

Similarly, T-type channels are important in various physiological processes like secretion of transmitters and hormones [38]. At the cellular level, these channels regulate cell cycle progression, proliferation, and survival $[39,40]$. Studies show varying expression of T-type channels in cell cycle phases. A maximum expression (90\% increase) of T-type channels is evident in the S-phase and at the beginning of M-phase of the cell cycle. Moreover, increased expression of T-type channels is observed in cancer of breast, bladder, lung, and liver [40]. Knockdown experiments of these channels in MCF-7 breast cancer cells resulted in two different outcomes: The silencing of $\mathrm{Ca}_{\mathrm{v}} 3.1$ enhanced proliferation, and the silencing of $\mathrm{Ca}_{\mathrm{v}} 3.2$ decreased proliferation [41]. As a result, $\mathrm{Ca}_{\mathrm{v}} 3.1$ gene appears to have a tumor suppressor role while $\mathrm{Ca}_{\mathrm{v}} 3.2$ possesses pro survival activity [41]. VGCCs are thus highly expressed in various cancers and thus contribute to the regulation of carcinogenesis. Despite the fact that molecular mechanisms of their activity is still not clear, VGCCs may represent a diagnostic marker and therapeutic target in the cancer treatment [34]. Moreover, PMCA is a major efflux pathway in $\left[\mathrm{Ca}^{2+}\right]_{\mathrm{i}}$-regulation, and impaired PMCA function results in $\mathrm{Ca}^{2+}$ overload and cell death. Glycolytic inhibition and subsequent ATP depletion impairs PMCA function and induces cells to undergo apoptosis [42]. 


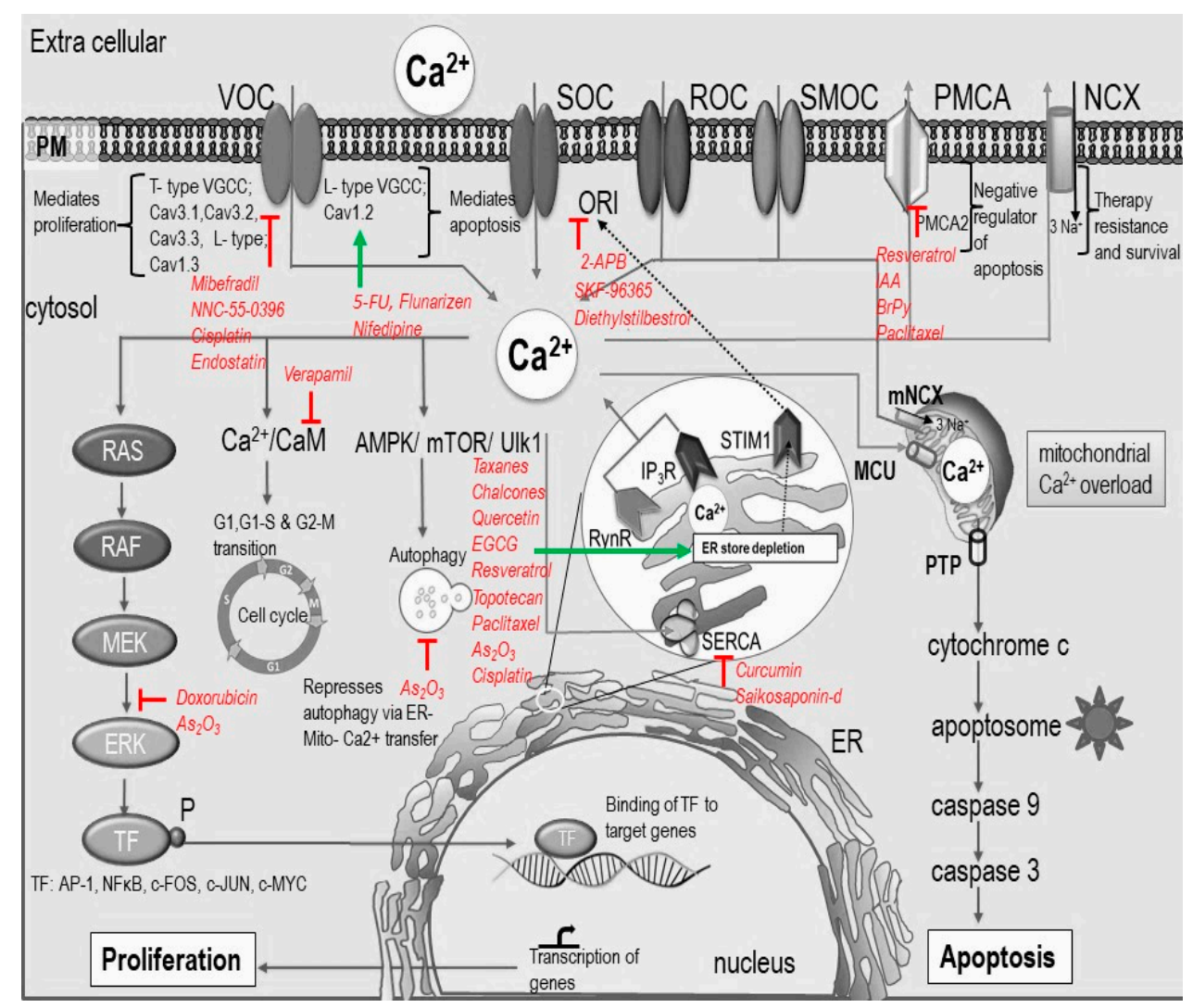

Figure 2. Intra-cellular calcium response to anti-cancer agents. This schematic representation shows the effect of anti-cancer agents on calcium signaling and its downstream effect on apoptosis and proliferation. Anti-cancer drugs can target different calcium channels and pumps on the plasma membrane, ER, and mitochondria. ER-mitochondrial $\mathrm{Ca}^{2+}$ transfer plays an important role in apoptosis and many anti-cancer drugs target ER to induce apoptosis. Anti-cancer drugs can also be anti-proliferative (e.g., Doxorubicin) by targeting $\mathrm{Ca}^{2+}$-signaling that regulate various proliferation pathways and cell cycle progression. Green arrows represent activation and red lines represent a block.

\subsection{Store Operated Calcium Entry in Cell Proliferation}

Store operated calcium channels (SOC) on the plasma membrane generate calcium signals in a variety of cell types [43] and are considered to be the main calcium entry in non-excitable cells. Moreover, SOC entry controls a wide range of physiological functions such as apoptosis, proliferation, and migration [44]. Significantly, the activation of SOC entry is mediated via internal $\mathrm{Ca}^{2+}$-efflux [8]. $\mathrm{Ca}^{2+}$ stored in the ER and the mitochondria actively contributes to $\left[\mathrm{Ca}^{2+}\right]_{\mathrm{i}}$-signals as the $\mathrm{Ca}^{2+}$ influx is triggered by a calcium release from the ER which is mediated through stimulation of surface receptors [45]. Two important proteins, STIM1 on the ER (calcium sensor) and Orai1 (pore forming protein) of the calcium release-activated channels (CRAC) on the plasma membrane are involved in SOC entry. $\mathrm{Ca}^{2+}$-influx mediated by SOC entry activates "NFAT" transcription factor via STIM1 and Orai1, driving the proliferation pathway [45]. Proliferation is also positively regulated by SOCE (store operated calcium entry) through PI3K/Akt pathway [46]. A dysregulated STIM1/Orai1/SOC axis is implicated in many pathological conditions such as SCID (severe combined immune deficiency syndrome); cardiovascular and pulmonary diseases; and cancer of the breast, colon, and, esophagus [44]. In breast cancer, STIM1 and STIM2 contribute to invasion, migration, and SOC-dependent TGF $\beta$-mediated EMT (epithelial-mesenchymal transition), and their overexpression significantly correlates with the poor survival [47]. Breast cancer is associated with an increased level of Orai1 and knockdown of Orai1 using siRNA in MCF-7 and MDA-MB-231 cells showed reduced SOC activity and decreased number of viable cells [48]. Moreover, in the ER positive BC cell line MCF-7 and T47D knockdown of Orai3 resulted in 
cell cycle arrest at G1 phase and induction of apoptosis [49]. Furthermore, in colon cancer cells the SOC-dependent migration was mediated by a complex of protein involving SK3/TRPC1/Orai1 [50]. Additionally, inhibition of SOC activity by non-steroidal anti-inflammatory drugs (NSAIDs) attenuated proliferation in the HRT-18 colon cancer cell line [51]. As the SOC entry is considered to be primary $\mathrm{Ca}^{2+}$ entry mechanism in most cancer types (thus contributing to cancer cell migration, invasiveness, and metastasis), there is a high interest in development of selective SOC entry blockers to prevent cancer metastasis $[52,53]$.

\subsection{SERCA in Cell Proliferation}

SERCA is a calcium pump located in endoplasmic reticulum which maintains a low calcium level and thus enables signaling of various physiological processes [54]. Inhibition of SERCA by thapsigargin empties the ER-Ca ${ }^{2+}$ store and inhibits proliferation. Importantly, different isoforms of SERCA show altered expression in different types of cancers. For instance, SERCA2 is linked to the malignant progression of colorectal SW480 cells while its overexpression is associated with increased proliferation and migration of cancer cells mediated via activation of MAPK and AKT signaling pathways [55]. A close link between SERCA inhibition by thapsigargin and the ER calcium pool content depends on the epidermal growth factor (EGF) concentration, as was observed in LNCaP prostate cancer cells. The results confirmed the increase of ER-Ca ${ }^{2+}$ in the presence of EGF $(200 \pm 19 \mu \mathrm{M})$ when compared to control without EGF $(90 \pm 5 \mu \mathrm{M})$. In addition, higher expression of SERCA2b in the presence of growth factors such as EGF, DHT (dihydrotestosterone) serum, and the ER-Ca ${ }^{2+}$-pool concentration is important in regulating proliferation of LNCaP human prostate cancer cells [56]. A significant difference in $\left[\mathrm{Ca}^{2+}\right]_{i}$ homeostasis is observed in normal human bronchial epithelial (NHBE) cells vs. different lung cancers. Lung cancer cells showed lower ER-Ca ${ }^{2+}$-content which correlated with reduced expression of SERCA2b and increased expression of $\mathrm{IP}_{3} \mathrm{R}$ and calreticulin (a calcium buffering protein in the ER) [57].

\subsection{ER and Mitochondrial Axis in Proliferation}

High resolution microscopy images show a dynamic network of ER and mitochondria juxtaposed at various domains. These are identified as microdomains with high $\left[\mathrm{Ca}^{2+}\right]_{i}$ related to $\mathrm{IP}_{3}$ mediated $\mathrm{Ca}^{2+}$-release and are important determinants of $\left[\mathrm{Ca}^{2+}\right]_{i}$-signaling, thus controlling survival, autophagy, apoptosis, metastasis, and invasiveness [58,59]. Mitochondrial calcium homeostasis is essential for cell survival and metabolic regulation $[60,61]$. Therefore, mitochondria play a dual role in death and survival, and dysregulation of mitochondrial $\mathrm{Ca}^{2+}$-homeostasis is associated with various diseases including cancer [62]. Importantly, mitochondrial calcium uniporter (MCU) is the channel enabling accumulation of $\mathrm{Ca}^{2+}$ in the matrix [62]. Aberrant expression or functioning of MCU complex contributes to cancer [62]. Significantly, integrity of the mitochondrial membrane, a sustained mitochondrial membrane potential, mitochondrial $\mathrm{Ca}^{2+}$ homeostasis regulated by $\mathrm{Na}^{+} / \mathrm{Ca}^{2+}$ exchanger, and MCU may ensure cell survival. Conversely, loss of mitochondrial potential, $\mathrm{Ca}^{2+}$ overload and opening of the permeability transition pores (PTP) activates an apoptotic cascade [63].

\section{7. $\left[\mathrm{Ca}^{2+}\right]_{i}$ and Apoptosis}

Programmed cell death, also known as "apoptosis", is crucial for such normal cell physiological functions as turnover and cell death. There are two main signaling pathways (intrinsic and extrinsic) that culminate in apoptosis [64]. Mitochondria have a dual role in cell death and survival which is well documented. The intrinsic pathway is marked by mitochondrial $\mathrm{Ca}^{2+}$ overload, which results in the release of cytochrome $c$. Cytochrome $c$ then combines with APAF-1 and, along with ATP and procaspase 9 , forms the apoptosome, followed by activation of procaspase 9 to active caspase 9 , which triggers the activation of effector caspases downstream, ultimately resulting in the death of the cell. In addition to caspases, calpains are another class of cysteine proteases which require calcium for their activation. Importantly, calpains mediate apoptosis as a response of ER stress [61]. In fact, 
mitochondria, as the main provider of cellular energy, also function as a regulator of $\left[\mathrm{Ca}^{2+}\right]_{\mathrm{i}}$. There is a calcium crosstalk in the domain between ER and mitochondria known as mitochondria-associated membrane (MAM). Importantly, tumor cells modify their MAM which leads to alterations of tumor homeostasis and consequently to promotion of migration, invasiveness, metastasis, resistance to apoptosis, and induction of EMT [63]. Furthermore, $\left[\mathrm{Ca}^{2+}\right]_{\mathrm{i}}$ homeostasis also may be influenced by $\mathrm{Bcl}-2$ proteins. Overall, members of the Bcl-2 family play an important role in cell death and survival via modulation of $\mathrm{Ca}^{2+}$-transport at the ER, plasma membrane, or mitochondria [65].

Furthermore, VDAC1 (voltage-dependent anion channel 1), which is located on the outer mitochondrial membrane (OMM), allows efflux and influx of ions and metabolites. It has a significant role in cell survival and death. It facilitates mitochondrial-mediated cell death in association with apoptotic proteins, causes the release of cytochrome $c$, and induces apoptosis. Furthermore, $\left[\mathrm{Ca}^{2+}\right]_{i}$ rise elevates VDAC1 expression and positively modulate apoptosis $[66,67]$. SOCE is also involved in apoptosis as SOC channels are activated or opened upon depletion of $\mathrm{Ca}^{2+}$ from the ER store. This causes an influx of $\mathrm{Ca}^{2+}$ from the extracellular pool, resulting in increased $\left[\mathrm{Ca}^{2+}\right]_{i}$ which is related to activation of apoptosis. The release of $\mathrm{Ca}^{2+}$ from ER store as well as influx of $\mathrm{Ca}^{2+}$ through the SOC channels influence apoptosis. As reported by Wertz and Dixit, the release of $\mathrm{Ca}^{2+}$ from the intracellular store alone activated apoptosis via caspase $3 / 7$ in LNCaP prostate cancer cells [68]. Similarly, Skryma et al. demonstrated no requirement for the $\mathrm{Ca}^{2+}$ entry from the store in thapsigargin-treated LNCaP cells [22]. Importantly, the events that contributed to apoptosis following ER calcium depletion led to ER stress and initiation of death signals [69]. In this finding an exclusive relationship between ${\mathrm{ER}-\mathrm{Ca}^{2+}}^{2+}$ store/bcl-2/apoptosis was identified in LNCaP cells treated with thapsigargin [69]. Moreover, inhibition of SERCA by thapsigargin in prostate and breast cancer cells led to drainage of the ER-Ca ${ }^{2+}$ stores, which was followed by reduction in cell proliferation and consequent apoptosis [69].

\section{Targeting Calcium Signaling for Anti-Cancer Therapy}

Anti-cancer drugs have multiple modes of action and, based on their mechanism of action, can interfere at the DNA level, act as antimetabolites, inhibit enzyme synthesis, and inhibit microtubule function. In the past decade, much attention has been drawn to calcium signaling. Altered calcium signaling is crucial for the development and progression of cancer through the induction of proliferation, invasion, and metastasis [70]. Figure 2 and Table 1 summarize anti-cancer drugs and their $\left[\mathrm{Ca}^{2+}\right]_{\mathrm{i}}$ mediated induction of cell death. 
Table 1. Interference of anti-cancer agents with different mechanisms of calcium homeostasis. This table illustrates which calcium mediating processes are involved, the actual concentrations (doses) needed, the experimental model, and whether apoptosis or proliferations are involved.

\begin{tabular}{|c|c|c|c|c|c|c|c|}
\hline Drug Class & Drugs & Axis/Mechanism of Induction of Cell Death & Concentration Range & Apoptosis & Proliferation & Cell Line & References \\
\hline $\begin{array}{l}\text { Platinum agents } \\
\text { (cytotoxic } \\
\text { alkylating agent) }\end{array}$ & Cisplatin & $\begin{array}{l}{\left[\mathrm{Ca}^{2+}\right]_{\mathrm{i}} \uparrow \uparrow \text { by influx of extra cellular calcium. }} \\
{\left[\mathrm{Ca}^{2+}\right]_{\mathrm{i} \uparrow} \uparrow / \text { ER stress / mitochondrial } \mathrm{Ca}^{2+} \text { over load / caspase }} \\
3 \text { activation. }\end{array}$ & $\begin{array}{c}1 \mu \mathrm{M} \\
5 \mu \mathrm{g} / \mathrm{ml}\end{array}$ & $\uparrow \uparrow$ & $\downarrow \downarrow$ & $\begin{array}{l}\text { MCF-7 } \\
\text { SH-SY5Y } \\
\text { HeLa-S3 }\end{array}$ & {$[31,71-73]$} \\
\hline Anti-metabolites & 5-Fluorouracil & $\begin{array}{l}\mathrm{Ca}^{2+}+\mathrm{CaM}-\mathrm{p} 53 \text { activation, } \mathrm{Ca}^{2+} \text { influx partially through L-type } \\
\mathrm{Ca}^{2+} \text { channel. } \\
\mathrm{Ca}^{2+} \text { entry through TRPV1 / mitochondrial ROS production / } \\
\text { caspase } 8 .\end{array}$ & $\begin{array}{l}768 \mu \mathrm{M}, \\
25 \mu \mathrm{M}\end{array}$ & $\uparrow \uparrow$ & $\downarrow \downarrow$ & $\begin{array}{l}\text { HCT116 } \\
\text { MCF-7 }\end{array}$ & {$[74,75]$} \\
\hline $\begin{array}{l}\text { Inorganic arsenic } \\
\text { compounds }\end{array}$ & $\mathrm{As}_{2} \mathrm{O}_{3}$ & $\begin{array}{l}\mathrm{IP} 3 \mathrm{R}, \mathrm{RyR} /\left[\mathrm{Ca}^{2+}\right]_{\mathrm{i}} \uparrow \uparrow / \mathrm{DNA} \text { damage } / \text { caspase } 3 . \\
\uparrow \uparrow \mathrm{ER}-\mathrm{mitochondrial} \mathrm{Ca}^{2+} \text { transfer. } \\
\downarrow \downarrow \mathrm{ERK} 1 \text { and ERK2 }\end{array}$ & $1 \mu \mathrm{M}$ & $\uparrow \uparrow$ & $\downarrow \downarrow$ & $\begin{array}{l}\text { SH-SY5Y } \\
\text { Pml- } / \text { mice } \\
\text { NB4 cells } \\
\text { U937 }\end{array}$ & {$[31,76-78]$} \\
\hline Anthracyclines & Doxorubicin & $\begin{array}{l}{\left[\mathrm{Ca}^{2+}\right]_{\mathrm{i}} \text { modulation - ERK1/2 inactivation, activation of pro }} \\
\text { apoptotic BIM pathway and mitochondrial } \mathrm{Ca}^{2+} \text { overload. }\end{array}$ & $500 \mathrm{nM}-1 \mu \mathrm{M}$ & $\uparrow \uparrow$ & $\downarrow \downarrow$ & MDA-MB-231 & [79] \\
\hline Taxanes & $\begin{array}{l}\text { Paclitaxel } \\
\text { Docetaxel }\end{array}$ & $\begin{array}{l}\text { In activation of PMCA2/calcineurin A and activation of calcineurin } \\
\text { A /NFAT pathway/ } \uparrow \uparrow \text { pro-apoptotic protein Fas ligand. } \\
\left.\text { External calcium influx, inhibition of bcl2/ IP3R-ER-[Ca }{ }^{2+}\right]_{\mathrm{i}} \text {. }\end{array}$ & $\begin{array}{c}1 \mathrm{nM} \\
10^{-6} \mathrm{M}\end{array}$ & $\uparrow \uparrow$ & & $\begin{array}{l}\text { MDA-MB-231 } \\
\text { MCF-7 } \\
\text { MDA-MB-468 }\end{array}$ & {$[80,81]$} \\
\hline Natural compounds & $\begin{array}{l}\text { Chalcones } \\
\text { Quercetin } \\
\text { EGCG } \\
\text { Piceatannol } \\
\text { Etoposide; } \\
\text { (semi-synthetic) } \\
\text { Resveratrol } \\
\text { Curcumin } \\
\text { Saikosaponin-d }\end{array}$ & $\begin{array}{l}\mathrm{Ca}^{2+} / \mathrm{ER} \text { stress / caspase } 12 . \\
\mathrm{G}-\text { protein } / \mathrm{IP} 3 \mathrm{R}-\mathrm{ER}-\left[\mathrm{Ca}^{2+}\right]_{\mathrm{i}} / \text { modulation of } \mathrm{p} 53 \text { / transcription of } \\
\text { pro-apoptotic genes. } \\
\text { SERCA } \downarrow \downarrow \text { activity } /\left[\mathrm{Ca}^{2+}\right]_{\mathrm{i}} \uparrow \uparrow / \text { increased mitochondrial } \\
\mathrm{Ca}^{2+} \text { uptake. } \\
\mathrm{SERCA} \downarrow \downarrow /\left[\mathrm{Ca}^{2+}\right]_{\mathrm{i}} \uparrow \uparrow / \text { ER stress / Autophagy mediated cell death. }\end{array}$ & $\begin{array}{c}30-40 \mu \mathrm{M} \\
50-100 \mu \mathrm{M} \\
10 \mu \mathrm{M}\end{array}$ & $\uparrow \uparrow$ & & $\begin{array}{l}\text { L1210 } \\
\text { MDA-MB-231 } \\
\text { MYCN2 } \\
\text { HeLa } \\
\text { SW480 (colon) } \\
\text { MCF-7 }\end{array}$ & {$[55,82-86]$} \\
\hline $\begin{array}{l}\text { Camptothecin } \\
\text { analog }\end{array}$ & Topotecan & Increased $\left[\mathrm{Ca}^{2+}\right]_{\mathrm{i}}$, altered expression of calcium regulating proteins. & $0.01 \mu \mathrm{M}$ & $\uparrow \uparrow$ & $\downarrow \downarrow$ & SH-SY5Y & [87] \\
\hline $\begin{array}{l}\text { Hormonal receptor } \\
\text { modulator }\end{array}$ & Tamoxifen & $\begin{array}{l}{\left[\mathrm{Ca}^{2+}\right]_{\mathrm{i}} \uparrow \uparrow \text { by influx of extra cellular calcium and release of } \mathrm{Ca}^{2+}} \\
\text { from multiple stores. } \\
\text { VGCC }\end{array}$ & $5-10 \mu \mathrm{M}$ & $\uparrow \uparrow$ & & $\begin{array}{l}\text { MCF-7 } \\
\text { MG63 } \\
\text { ZR-75-1 } \\
\text { SCC } \\
\text { BFTC }\end{array}$ & [88-92] \\
\hline $\begin{array}{l}\text { DNA methylation } \\
\text { and HDAC } \\
\text { modulators }\end{array}$ & $\begin{array}{l}\text { TSA } \\
\text { Azacitidine } \\
\text { Digitoxin } \\
\text { Pyrithion zinc } \\
\text { Disulfiram }\end{array}$ & $\begin{array}{l}\uparrow \uparrow \text { SERCA3 / apoptosis. } \\
\text { SOC / }\left[\mathrm{Ca}^{2+}\right]_{\mathrm{i}} \uparrow \uparrow / \text { CamK / via MeCP2 / reactivation of tumor } \\
\text { suppressor genes. }\end{array}$ & $50 \mathrm{nM}-5 \mu \mathrm{M}$ & $\uparrow \uparrow$ & & $\begin{array}{l}\text { KATO-III } \\
\text { (gastric } \\
\text { carcinoma) } \\
\text { YB5 (colon) }\end{array}$ & {$[93,94]$} \\
\hline
\end{tabular}




\section{1. $\left[\mathrm{Ca}^{2+}\right]_{0}$ Influences Drug Efficiency}

$\left[\mathrm{Ca}^{2+}\right]_{\mathrm{o}}$ influences the mechanism of action of paclitaxel in inducing apoptosis in breast cancer cells. Apoptosis induced by low dose paclitaxel is independent of $\left[\mathrm{Ca}^{2+}\right]_{0}$ whereas for high dose paclitaxel, normal $\left[\mathrm{Ca}^{2+}\right]_{\mathrm{o}}$ is critical for inducing apoptosis in MDA-MB-468 TNBC cells, which is mediated via capacitative $\mathrm{Ca}^{2+}$-entry [81]. Similarly, low $\left[\mathrm{Ca}^{2+}\right]_{0}$ reduced anti-cancer action of tamoxifen (TM) on HepG2, human hepatoblastoma cells. To understand the route of $\mathrm{Ca}^{2+}$ entry, $\mathrm{Ca}^{2+}$ channel blockers nifedipine and verapamil were used, but neither of them reversed the effect of TM, while flufenamic effectively reversed the effect of TM. A non-selective cation channel (NSCC) blocker caused significant inhibition of TM-induced apoptosis, indicating NSCC as the main route of $\mathrm{Ca}^{2+}$-influx [95]. Modifying the $\left[\mathrm{Ca}^{2+}\right]_{\mathrm{o}}$ improved the cytotoxic action of CDDP and topotecan [87].

\subsection{Anti-Cancer Drugs-Induced $\left[\mathrm{Ca}^{2+}\right]_{i}$ Modulation Triggers Apoptosis}

\subsubsection{Platinum Drugs}

Cisplatin (CDDP; cis-diamminedichloridoplatinum) is used in treatment of solid tumors and modulates $\left[\mathrm{Ca}^{2+}\right]_{\mathrm{i}}$. It blocks voltage gated channels at higher concentrations [96] but allows calcium entry through other channels [31] and releases calcium from the stores [97]. In neuroblastoma (NB) cells, CDDP alters the expression of key calcium regulating proteins such as RyR and IP3R [98]. HeLa cells, when treated with CDDP for $16 \mathrm{~h}$, showed an increase in $\left[\mathrm{Ca}^{2+}\right]_{i}$ followed by an increased expression of VDAC1 and oligomerization of VDAC1-triggered cytochrome $c$ release and concomitant apoptosis [67]. An increased expression of VDAC1 sensitizes cancer cells to anti-cancer drugs via $\mathrm{Ca}^{2+}$-dependent mechanism. A study in HeLa S3 cells revealed a rise in $\left[\mathrm{Ca}^{2+}\right]_{i}$ following CDDP treatment, which correlated with the activation of calpain, an important molecule in the induction of apoptosis [31]. Increase in CDDP concentration caused an increase in $\left[\mathrm{Ca}^{2+}\right]_{\mathrm{i}}$ in MCF-7 breast cancer cells [72]. S100A9, a calcium-binding protein, is associated with cancer progression and has been reported to influence squamous cervical cancer cells' sensitivity to CDDP treatment. Here, down-regulation of S100A9 protein resulted in increased cell death potentiated by altering pro survival AKT/ERK-FOXO1-Nanog signaling pathway [99]. Another study emphasized the role of NCX and NCXK $\left(\mathrm{K}^{+}\right.$dependent $\mathrm{Na}^{+} / \mathrm{Ca}^{2+}$-exchangers) in cisplatin chemotherapy of ovary carcinoma cells. In this study using A2780 ovarian cancer cell line, the expression of NCX 3 NCKX4, NCKX5, and NCKX6 isoform was higher in the CDDP resistant cell line. NCX inhibitor KB-R7943 $(10 \mu \mathrm{M})$ significantly improved CDDP sensitivity there by confirming the role of NCX in therapy resistance [100]. Most of the anti-cancer drugs have side effects. Oxaliplatin, a platinum-based drug, undergoes activation with the release of oxalate and the generation of oxalate metabolite is often associated with oxaliplatin associated peripheral neuropathy. Schulze et al. examined the mechanism of oxaliplatin mediated calcium signaling and its role in oxaliplatin-induced peripheral neuropathy. A prolonged exposure to the drug induced changes in the ER calcium load and IP3R mediated calcium signaling, though there was no activation of cellular temperature sensors-TRP channels [101]. Strategies to selectively target cancer cells by sparing the normal cells is a wise approach. The new platinum drug $\left[\mathrm{Pt}\left(\mathrm{O}, \mathrm{O}^{\prime}\right.\right.$-acac $)(\gamma$-acac)(DMS)] $(\mathrm{PtAcD})$ is selectively toxic on the breast cancer cell line and less toxic on normal breast cells due to differentially activated JNK and p38 [102]. Research on next generation platinum drugs (e.g., (Pt(IV) carboxylate complexes) are underway with more efficacy and less side effects.

\subsubsection{Anti-Metabolites}

5-Fluorouracil (5-FU), an anti-metabolite which interferes with DNA synthesis and repair, is used for treatment of breast, skin, pancreatic cancer, etc. Its mechanism of apoptosis induction in HCT116 involved the $\mathrm{Ca}^{2+}$-influx from extracellular space, which was detected as early as $1.5 \mathrm{~h}$ after exposure to 5 -fluorouracil. Consequently, activated p53 was detected after $5 \mathrm{~h}$ of 5-FU treatment followed by activation of caspase and induction of apoptosis. Elevation of $\left[\mathrm{Ca}^{2+}\right]_{\mathrm{i}}$ is an early event in the apoptosis of HCT116 mediated via $\mathrm{Ca}^{2+}-\mathrm{CaM}$-p53 axis [74]. Another study reported the involvement 
of TRPV 1 channel in 5-FU induced cell death in MCF-7 cells, which involved rise in $\left[\mathrm{Ca}^{2+}\right]_{\mathrm{i}}$ followed by mitochondrial ROS production and caspase activation [75]. TRPV1 is a non-specific cation channel sensitive to temperature, $\mathrm{pH}$, and capsaicin.

\subsubsection{Inorganic Arsenic Compounds}

Arsenic trioxide $\left(\mathrm{As}_{2} \mathrm{O}_{3}\right)$ is an anti-cancer drug used for the treatment of hematologic cancers such as chronic myelogenous leukemia (CML) [103]. Various studies have reported $\mathrm{As}_{2} \mathrm{O}_{3}$ modulating different $\mathrm{Ca}^{2+}$-dependent/independent signal transduction pathways, resulting in the induction of apoptosis, inhibition of angiogenesis, and proliferation [104]. Receptors on the ER (IP3R and ryanodine $\mathrm{R})$ are involved in the induction of apoptosis by elevating $\left[\mathrm{Ca}^{2+}\right]_{\mathrm{i}}$. Treatment with $1 \mu \mathrm{M} \mathrm{As} \mathrm{s}_{2} \mathrm{O}_{3}$ in SH-SY5Y NB cells elevated $\left[\mathrm{Ca}^{2+}\right]_{i}$ by ER-Ca ${ }^{2+}$ store depletion [24]. Calcium imaging showed three types of signals: A slow and steady increase in $\left[\mathrm{Ca}^{2+}\right]_{\mathrm{i}}$, transient calcium elevation, and spikes. Mechanistic studies have revealed increased $\mathrm{H}_{2} \mathrm{O}_{2}$ level, Bax expression, growth arrest at the G1 phase of the cell cycle, and inhibition of vascular endothelial growth factor (VEGF) upon $\mathrm{As}_{2} \mathrm{O}_{3}$ treatment [105,106]. Missiroli et al. [77] elucidated a $\mathrm{Ca}^{2+}$-dependent mechanism that coordinately regulated apoptosis and autophagy in cancer. They investigated $\mathrm{pml}$, a tumor suppressor gene related to the pathogenesis of acute promyelocytic leukemia. PML protein and its association with ER-mitochondrial contact sites were important in repressing autophagy, and treatment with $\mathrm{As}_{2} \mathrm{O}_{3}$ was shown to reduce the autophagy efficiency by modulating PML protein in NB4 leukemia cells [77]. Similar to CDDP treatment in HeLa cells, increased expression of VDAC1 is observed with $\mathrm{As}_{2} \mathrm{O}_{3}$ treatment in SKOV-3 cells (human ovarian carcinoma) and A549 cells (human lung adenocarcinoma alveolar basal epithelium).

\subsubsection{Anthracyclines}

Studies on doxorubicin, a chemotherapeutic drug belonging to the category anthracyclines, reported contrasting observations on the effect of $\mathrm{Ca}^{2+}$ on doxorubicin cytotoxicity. A counteracting mechanism of $\mathrm{Ca}^{2+}$ concentration on doxorubicin activity was reported by Nguyen et al. [107]. Here, $\left[\mathrm{Ca}^{2+}\right]_{0}$ concentration dependently suppressed the cytotoxic activity of doxorubicin in MCF-7 breast cancer cell line. High $\left[\mathrm{Ca}^{2+}\right]_{\mathrm{o}}\left(100\right.$ and $\left.140 \mathrm{mM} \mathrm{CaCl}_{2}\right)$ almost completely rescued the cells treated with $0.2 \mu \mathrm{g} / \mathrm{mL}$ of doxorubicin $\left(\mathrm{LD}_{50}\right)$. Mechanism revealed that $\mathrm{Ca}^{2+}$ activated V-ATPase (Vacuolar-type $\mathrm{H}^{+}$-ATPase), reduced the bioavailability of drug by acidifying the intracellular organelles and sequestering doxorubicin into subcellular compartments [107]. The finding emphasizes the observation that high $\left[\mathrm{Ca}^{2+}\right]_{\mathrm{o}}$ confers insensitivity to doxorubicin treatment. In another study, silencing of PMCA2 calcium channel increases the sensitivity of MDA-MB-231 to doxorubicin treatment. Doxorubicin and simvastatin treatment in breast cancer cells caused a persistent release of $\mathrm{Ca}^{2+}$, resulting in activation of proapoptotic BIM pathway and subsequent overload of mitochondrial $\mathrm{Ca}^{2+}$ triggering apoptosis. In addition, both drugs significantly reduced the activation of pro survival pathway ERK1/2 signaling, which is calcium-dependent in doxorubicin treatment [79].

\subsubsection{Taxanes}

Paclitaxel is an anti-cancer drug used for the treatment of solid tumors. In neuroblastoma cells (SH-SY5Y), paclitaxel at a low concentration (sub-micromolar concentration) induced $\mathrm{Ca}^{2+}$-oscillations independent of $\left[\mathrm{Ca}^{2+}\right]_{\mathrm{o}}$ or mitochondrial calcium but dependent on IP3R mediated calcium influx from ER. The molecular basis of paclitaxel induced cytosolic $\mathrm{Ca}^{2+}$-oscillation is due to the enhanced binding of protein neuronal $\mathrm{Ca}^{2+}$-sensor 1 (NCS-1) to IP3R [108]. Conversely, in MD-MBA-468 breast cancer cells under normal $\left[\mathrm{Ca}^{2+}\right]_{0}, \mathrm{Ca}^{2+}$ entered from the extracellular pool following low dose paclitaxel $\left(10^{-7} \mathrm{M}\right)$ treatment and was independent of ER store, but high dose paclitaxel $\left(10^{-6} \mathrm{M}\right)$ induced $\mathrm{Ca}^{2+}$-influx extracellularly and a gradual depletion of ER store occurred, culminating in apoptosis. The mechanism of paclitaxel-mediated apoptosis is dependent on $\left[\mathrm{Ca}^{2+}\right]_{\mathrm{o}}$ and dosage of the drug [81]. 


\subsubsection{Glucocorticoids}

Glucocorticoid (GC), a class of drugs that have multiple physiological effects such as immune suppression, cytotoxicity, and anti-inflammatory effects, is commonly used for hematological malignancies like leukemia, lymphoma, and myeloma [109]. GC modulates $\left[\mathrm{Ca}^{2+}\right]_{i}$ homeostasis in B lymphocytes, while $\left[\mathrm{Ca}^{2+}\right]_{\mathrm{i}}$ has a complex role in the induction of apoptosis by glucocorticoids. Release of $\mathrm{Ca}^{2+}$ from the stores initiates apoptosis in GC-treated lymphocytes. Here, $\mathrm{Ca}^{2+}$-dependent proteases such as calpain were activated, and blocking of calpain activation prevented GC-induced cell death [109]. Similar to doxorubicin, $\left[\mathrm{Ca}^{2+}\right]_{\mathrm{i}}$ attenuated dexamethasone sensitivity in acute lymphoblastic leukemia (ALL) cells. Dexamethasone increased $\left[\mathrm{Ca}^{2+}\right]_{\mathrm{i}}$ mainly by SOC-operated calcium entry [110].

\subsubsection{Natural Compounds}

Analysis of studies based on some natural compounds showed a $\mathrm{Ca}^{2+}$-dependent anti-cancer effect (see Table 1 and Figure 2). For example, Resveratrol induced $\mathrm{Ca}^{2+}$-dependent apoptosis through a biphasic $\left[\mathrm{Ca}^{2+}\right]_{\mathrm{i}}$-rise involving mitochondria, activation of calpain, and decreased SERCA activity $[85,111]$. Saikosaponin-d, a natural SERCA inhibitor, induced $\mathrm{Ca}^{2+}$ dependent autophagy mediated cell death via CaMKKb-AMPK-mTOR pathway [86]. In another study, epibrassinolide, a polyhydroxylated sterol derivative, induced $\mathrm{Ca}^{2+}$ sequestration and thus caused an alteration in the ER pathway, consequent ER stress, and progress to apoptosis [112]. Using a model of endometriosis, Park et al. described that luteolin exerts antiproliferative and apoptotic effects in pre-neoplastic human endometrial cells VK2/E6E7 and End1/E6E7. The anti-cancer effects of luteolin were linked with an increase in cytosolic calcium levels, ROS production, and lipid peroxidation in cells and altered regulation of PI3K/AKT and MAPK cell signaling, as well as the expression of CCNE1 [113]. Using the same model and cells, the same group showed that delphinidin exerts proapoptotic and antiproliferative effects mediated by MAPK and PI3K/AKT signaling proteins. These effects were accompanied by a decrease in the phosphorylation of ERK1/2, AKT, p70S6K, S6 and an increase in the phosphorylation of p38 MAPK and p90RSK [114]. Delphinidin induced apoptosis in human endometrial cells by decreasing the mitochondrial membrane potential and increasing the $\left[\mathrm{Ca}^{2+}\right]_{\mathrm{i}}$. Safrole-mediated apoptotic cell death in HSC-3 cells was associated with an increase of cytosolic $\mathrm{Ca}^{2+}$ levels, a decrease in the mitochondrial membrane potential, and activation of Fas-dependent pathways [115]. Curcumin induced apoptosis in HepG2 cell, which was associated with the disruption of mitochondrial membrane potential and disturbance of intracellular free $\mathrm{Ca}^{2+}$ concentration [116]. Natural products are potential drug candidates which can be considered for combination therapy as this strategy can increase sensitivity to chemotherapy by targeting multiple pathways and, therefore, reduce the side effects.

\subsubsection{Hormonal Receptor Modulator}

Tamoxifen (TM) is an estrogen receptor modulator commonly used for breast cancer prevention and treatment. Data from several sources have identified $\left[\mathrm{Ca}^{2+}\right]_{\mathrm{i}}$ modulation by tamoxifen, consistent with cytotoxicity in tumor cells $[89,91,92]$. In ZR-75-1 human breast cancer cells, treatment with tamoxifen at a concentration above $2 \mu \mathrm{M}$ induced an early $\left[\mathrm{Ca}^{2+}\right]_{\mathrm{i}}$ rise due to release from stores as well as entry from extracellular space [91]. A detailed study by Zhang et al. on calcium dynamics in tamoxifen-treated breast cancer cells and glioma cells revealed increase in $\left[\mathrm{Ca}^{2+}\right]_{i}$ level and spatial expansion of calcium waves by 30-150\%. Mechanistic studies revealed tamoxifen-induced calcium-depended cytotoxicity facilitated via enhanced purinergic signaling [88]. Furthermore, in human osteosarcoma cells a sustained increase in $\left[\mathrm{Ca}^{2+}\right]_{i}$ due to release of calcium from multiple stores (phospholipase $\mathrm{C}$-independent manner) was recorded following $1 \mu \mathrm{M}$ tamoxifen treatment [90]. The antiproliferative effect of tamoxifen in human non-melanoma skin cancer cells A431, DJM-1, and HSC-1 is also related to an increase of $\left[\mathrm{Ca}^{2+}\right]_{\mathrm{i}}[92]$. 


\subsubsection{Epigenetic Modulators}

Recent studies discovered a prominent role of epigenetic deregulation linked to cancers. The most important epigenetic changes, DNA methylation and histone post-translational modification (methylation and acetylation), result in gene silencing of tumor suppressor genes (TSG) or up/down regulation of other genes. A recent article highlights the role of $\left[\mathrm{Ca}^{2+}\right]_{i}$-signaling in re-activating tumor suppressor genes via CamK. Reactivation of silenced TSG by epigenetic drug azatidine revealed a novel mechanism, which traced back to $\mathrm{Ca}^{2+}$-dependent activation of $\mathrm{CamK}$ and subsequent release of MeCP2 methyl-binding protein from promotion of the silenced genes [94]. Epigenetic silencing of gene ATP2A3, which codes for SERCA3, is down-regulated in gastric and colon tumors. Treatment of KATO-III cells with butyrate, trichostatin A, and 5-azacytidine increased the expression of SERCA3 and was correlated with increased apoptosis and decreased viability [93]. Mitochondrial $\mathrm{Ca}^{2+}$-overload is suggested as a key trigger for programmed cell death. MCU, together with its regulatory subunits, mitochondrial calcium uptake 1 (MICU1) and mitochondrial calcium uniporter regulator 1 (MCUR1), which are responsible for mitochondrial- $\mathrm{Ca}^{2+}$ entry, provide novel molecular tools to evaluate this process. Regarding epigenetic modulations of these mechanisms, recent data have also demonstrated that miR-25 reduces mitochondrial $\mathrm{Ca}^{2+}$ uptake via $\mathrm{MCU}$, resulting in suppression of apoptosis. It is shown that down-regulation of MCU in human colon cancer cells correlates with miR-25 aberrant expression, pointing the importance of mitochondrial $\mathrm{Ca}^{2+}$ regulation in apoptosis.

\subsection{Calcium Dependent Modulation of Aerobic Glycolysis by Anti-Cancer Agents}

Warburg effect (aerobic glycolysis) is a mechanism observed in tumor energy metabolism promoting tumor growth and survival. Here, cells observe excess uptake of glucose and break down of glucose to pyruvate and lactate even in the presence of oxygen and a functional mitochondria $[117,118]$. Hence cancer cells exhibit altered $\mathrm{Ca}^{2+}$-dependent ATPase function. Chakraborty et al. (2017) documented that Mitochondrial Calcium Uptake 1 (MICU1/CBARA1), the gatekeeper of mitochondrial $\mathrm{Ca}^{2+}$-uptake, forces aerobic glycolysis and chemoresistance in ovarian cancer cells [119]. Another study showed that an increased expression of transient receptor potential canonical channel (TRPC5) enhances $\left[\mathrm{Ca}^{2+}\right]_{\mathrm{i}}$ level and results in chemoresistance and suppressed apoptosis in human colorectal cancer (CRC) cells [120]. In the follow-up of this study, Wang et al. demonstrated the crucial role of glycolysis in TRPC5 induced chemoresistance in CRC cells through maintaining $\left[\mathrm{Ca}^{2+}\right]_{i}$ homeostasis [121]. In vitro studies using dichloroacetate (DCA) demonstrated a shift in the metabolism from glycolysis to glucose oxidation in HeLa cells [122]. The changes in the metabolism modality led to increased intracellular $\mathrm{H}_{2} \mathrm{O}_{2}$ and $\mathrm{pH}$ levels, a drop in mitochondrial membrane potential, and the increase of caspase 3 and 9 . Regarding mechanism of action, the increased Kv1.5 expression and decreased $\left[\mathrm{Ca}^{2+}\right]_{i}$ appointed a positive feedback loop that caused the decrease in tonic inhibition of caspases. CDDP in combination with DCA exhibited synergy [122]. In vitro studies conducted in human PDAC cell lines (pancreatic cancer) treated with glycolytic inhibitors BrPy $500 \mu \mathrm{m}$ (3-bromopyruvate) and sodium iodoacetate $2 \mathrm{~mm}$ (IAA) resulted in glycolytic inhibition and ATP depletion. As a result, ATP depletion lead to impaired PMCA function and $\left[\mathrm{Ca}^{2+}\right]_{i}$ overload inducing cell death [42] (Figure 2). Furthermore, dexamethasone and prednisolone belonging to the class of glucocorticoids in ALL proved to shift cells' energy metabolism by suppressing glycolysis and increasing the anti-cancer cancer effect of etoposide [123].

\subsection{Calcium Modulators in Combination with Anti-Cancer Agents}

Tumor heterogeneity can be attributed to the cancer stem cell, tumor microenvironment, gene mutation, and epi-genetic changes. Consequently, cancer cells exposed to chemotherapeutic drugs are often not completely eliminated, and a few cells survive, generating resistant cancer cells. Originally, cancer was treated using single drugs but with the relapse and development of resistance to chemotherapy more trials with drug combinations yielded improved results. Hence, for an 
effective treatment, the tumor is exposed to a combination of anti-cancer agents targeting different pathways [124]. An important mechanism by which anti-cancer drugs induce cytotoxicity is by interfering with $\left[\mathrm{Ca}^{2+}\right]_{\mathrm{i}}$ either by binding or bringing conformational changes to calcium modulating proteins, including channels and pumps located at the plasma membrane, ER, or cytosol [23,25]. A considerable amount of literature has been published on the effect of calcium modulators on cell proliferation and apoptosis [125]. Over the years, research has emphasized the use of calcium modulators for the enhancement of anti-cancer drug efficiency [7]. A report in 1989 claimed a synergistic action of nifedipine with CDDP in B16a-Pt (cisplatin resistant murine tumor cell line) by a mechanism independent of VGCCs [126]. A novel approach using Riluzole, an activator of $\mathrm{Ca}^{2+}$-activated $\mathrm{K}^{+}$ channel $\left(\mathrm{K}_{\mathrm{Ca}} 3.1\right)$ and an inhibitor of $\mathrm{K}_{\mathrm{v}} 11.1$ increased the CDDP drug uptake and reversed CDDP resistance in the colorectal cancer cell line [127]. An extensive in vitro study in neuroblastoma chemotherapy using CDDP and topotecan showed enhanced cytotoxic effects with combinations of pharmacological modulators of $\left[\mathrm{Ca}^{2+}\right]_{i}$ regulating proteins [87]. Synergistic action with a panel of calcium channel modulators (cyclosporine A, thapsigargin, dantrolene, 2-APB) in CDDP/topotecan treatment showed promising results in neuroblastoma cell lines SH-SY5Y, NLF and IMR-32 [87]. For example, thapsigargin showed the highest cytotoxic effect by facilitating store-operated calcium entry and triggered apoptosis via ER-mitochondrial axis. Similarly, among the other modulators tested were cyclosporine A and 2-Aminoethoxydiphenyl borate (2-APB), which also induced ER stress and enhanced the cytotoxic effect of both CDDP and topotecan in neuroblastoma cell. 2-APB activates SOC mediated $\mathrm{Ca}^{2+}$-entry at a lower concentration, inhibits IP3R, and modulates TRP channels. Live cell calcium imaging studies performed in MCF-7cells pre-treated (30 min) with calcium channel modulators (caffeine, nimodipine, and ionomycin) showed decrease in CDDP-induced $\left[\mathrm{Ca}^{2+}\right]_{i}$ rise [72]. 1,2-Bis(2-aminophenoxy)ethane- $N, N, N^{\prime}, N^{\prime}$-tetraacetic acid tetrakis (acetoxymethyl ester) BAPTA-AM is a membrane-permeable calcium chelator widely used for $\left[\mathrm{Ca}^{2+}\right]_{i}$-signaling studies. A study in HeLa cells (human cervical cancer) indicated that combined treatment with (BAPTA-AM) or 2-APB attenuated CDDP-mediated $\left[\mathrm{Ca}^{2+}\right]_{\mathrm{i}}$ rise and apoptosis [31]. The above observations show the role of specific calcium channels in CDDP mediated $\left[\mathrm{Ca}^{2+}\right]_{i}$ rise. As in the case of dexamethasone, BAPTA-AM synergistically enhanced the cytotoxicity of dexamethasone in ALL cell lines [110]. On the contrary, another group reported that doxorubicin efficiency was compromised in the presence of BAPTA-AM in MDA-MB-231 breast cancer cells by preventing the inhibition of ERK1/2 phosphorylation, and was consistent with the attenuation of $\left[\mathrm{Ca}^{2+}\right]_{i}$ rise and decrease in cell death [79]. Huang et al. identified a $\left[\mathrm{Ca}^{2+}\right]_{\mathrm{i}}$-dependent apoptotic mechanism in PC3 human prostate cancer cells exposed to thapsigargin $(1-10 \mu \mathrm{M})$. Here, the rise in $\left[\mathrm{Ca}^{2+}\right]_{\mathrm{i}}$ was attributed to both $\mathrm{Ca}^{2+}$-influx from extracellular environment and depletion of ER stores [128]. Combination treatment with TRAIL (70 and $35 \mathrm{ng} / \mathrm{mL}$ ) and thapsigargin $(0.3$ and $0.6 \mu \mathrm{M})$ induced apoptosis and inhibited migration, invasion, and adhesion of ESCC cell lines (esophageal squamous cell carcinoma), demonstrating that this combination induces both apoptosis and inhibits metastasis [129]. In MCF-7 and MDA-MB-468 cells, apoptosis was triggered mainly due to a secondary and a delayed $(12-36 \mathrm{~h})$ calcium response to thapsigargin $(1 \mu \mathrm{M})$ [130]. Calcium modulating drugs can be used for enhancement of anti-cancer drug effect, whether it can mitigate side effects of anti-cancer treatment should be explored. Nifedipine, a dihydropyridine-type $\mathrm{Ca}^{2+}$-channel blocker improved the blood circulation and reduced hypoxia and hence achieved a better drug delivery towards tumor in an isolated limb perfusion experiment performed in rat bearing tumors [131]. Similarly, verapamil, a calcium channel blocker, improved the sensitivity of tumor to radiation by modifying the tumor vasculature [132].

Collectively, the combination of calcium channel modulators with anti-cancer drugs can have a beneficial effect with some combination of drugs.

\section{Conclusions and Future Directions}

Cancer research reveals that $\left[\mathrm{Ca}^{2+}\right]_{\mathrm{i}}$-signaling has substantial effects on proliferation and apoptosis. Prolonged increase in $\left[\mathrm{Ca}^{2+}\right]_{i}$ triggers apoptotic cascade and is the principle behind the action of 
many anti-cancer drugs. In the context of cancer, many drugs such as CDDP, topotecan, and $\mathrm{As}_{2} \mathrm{O}_{3}$ induce apoptosis depending on extra- and intracellular calcium. The modification of either $\left[\mathrm{Ca}^{2+}\right]_{\mathrm{o}}$ or $\left[\mathrm{Ca}^{2+}\right]_{\mathrm{i}}$ by calcium chelating agents can significantly augment the action of anti-cancer drugs such as doxorubicin and dexamethasone. This observation is relevant in a clinical context as caution should be exercised when using calcium-altering drugs and diets. Calcium signaling plays a dual role in cell survival and death. ER-mitochondrial $\mathrm{Ca}^{2+}$ fluxes are crucial in steps (cancer hallmarks) leading to cancer growth, and it is the most targeted site for many of the anti-cancer drugs (Figure 2). ER-mitochondrial $\mathrm{Ca}^{2+}$-flux, SOC entry, channels, and pumps on the PM coordinately control the fate of the cell. Hence, components of the calcium tool kit are potential targets of anti-cancer drugs. Nuclear calcium controls gene regulation, but its dependence on cytosolic calcium is a subject of debate. Hence, a drug which modulates $\left[\mathrm{Ca}^{2+}\right]_{\mathrm{i}}$ may or may not affect nuclear calcium, but there is no adequate information on this.

Dysregulated expression of many calcium regulation proteins is associated with migration, proliferation, apoptosis, angiogenesis, and invasion in cancer. However, it is beyond the scope of this review to discuss all the calcium signaling components dysregulated in various cancers. A growing body of evidence emphasizes targeting altered calcium homeostasis in cancer as a potential tool in cancer chemotherapy by modulating either the expression of calcium regulating proteins or their function. CDDP and topotecan are drugs identified to modulate the expression of $\mathrm{IP}_{3} \mathrm{R}$ and ryanodine in cancer chemotherapy, however, there are multiple calcium channel inhibitors/activators, which block/activate the function of various channels and thus modulate the apoptosis and proliferation of the cells. In this regard, many combinations of classical drugs with calcium channel regulators have improved efficacy within cancer chemotherapy. Moreover, a wide variety of drugs derived from natural compounds have proapoptotic and antiproliferative modes of action, such as topotecan, anthracyclins, and taxanes, and all modulate calcium signaling. Curcumin, safrole, luteolin, delphinidin, and other phytochemicals can potentially serve as molecules for developing novel anti-cancer drugs targeting proliferation and apoptosis in cancer cell via regulation of cytosolic $\mathrm{Ca}^{2+}$-levels. Reversing the glycolytic phenotype may trigger apoptosis in tumor cells, and thus represents an attractive therapeutic tool for anti-cancer clinical strategies. Selective targeting of the key functional enzymes of glucose metabolism through the elevation of $\left[\mathrm{Ca}^{2+}\right]_{i}$ level, which could lead to $\left[\mathrm{Ca}^{2+}\right]_{i}$ overload and promote apoptosis, is a new challenge for oncological research. Targeting epigenetic pathways is a newer approach in cancer chemotherapy, and using the calcium signaling pathway to reactivate silenced genes was recently introduced. In this regard, certain calcium-modulating agents have been proven to epigenetically increase the protein phosphorylation included in apoptosis/cell-cycle signaling, which is repressed in several cancers such as in the liver, pancreatic, breast, or prostate.

An increasing number of studies have identified and listed various proteins in the calcium signaling tool kit which are altered in various cancers [1]. Studies emphasize the important role of calcium cell signaling and various calcium regulating proteins in cancer development. However, further investigations are needed to explore precise molecular mechanisms of their anti-cancer action. Developing drugs against targets involving the calcium signaling tool kit is challenging as these proteins are ubiquitously present in all types of cells. It is important to critically classify those targets that are relevant to each type of cancer.

Author Contributions: The authors contributed as follows: Conceptualization, E.V. and D.B.; Literature Review and Resources, E.V.; S.M.S.; P.K. (Peter Kubatka) and A.L.; Writing-Original Draft Preparation, E.V.; Writing—Review and Editing, E.V.; S.M.S.; Z.S.; P.K. (Peter Kruzliak); A.L.; J.B; P.P.; P.K. (Peter Kubatka) and D.B.; Figure Preparation and Editing, E.V.; D.B.; Visualization, E.V.; S.M.S. and D.B.; Supervision, D.B. All authors reviewed the results and approved the final version of the manuscript.

Funding: This work was supported by the Bridge Funding Grant (Nov 2017-Dec 2018) from the Qatar National Research Fund (QNRF) and Weill Cornell Medicine-Qatar, Qatar Foundation, Doha, Qatar. The statements made herein are solely the responsibility of the authors.

Acknowledgments: We thank Steven Stay (Weill Cornell Medicine-Qatar, Doha, Qatar) for language corrections and linguistic and grammatical suggestions. 
Conflicts of Interest: The authors declare no conflict of interest.

\section{Abbreviations}

\begin{tabular}{|c|c|}
\hline$\left[\mathrm{Ca}^{2+}\right]_{\mathrm{i}}$ & intracellular calcium \\
\hline$\left[\mathrm{Ca}^{2+}\right]_{\mathrm{o}}$ & extra cellular calcium \\
\hline ALL & acute lymphoblastic leukemia \\
\hline APAF-1 & apoptotic protease activating factor 1 \\
\hline $\mathrm{As}_{2} \mathrm{O}_{3}$ & arsenic trioxide \\
\hline ATP & adenosine triphosphate \\
\hline $\mathrm{BrPy}$ & 3-bromopyruvate \\
\hline Calreticulin & calcium buffering protein in the ER \\
\hline CamK & $\mathrm{Ca}^{2+} /$ calmodulin-dependent protein kinase \\
\hline CaSR & calcium sensing receptor \\
\hline CDDP & cis-diamminedichloridoplatinum(II) \\
\hline CML & chronic myelogenous leukemia \\
\hline CRAC & channel Calcium release-activated channels \\
\hline CREB & cAMP response element-binding protein \\
\hline DJM-1 & a human skin squamous carcinoma cell line \\
\hline EC & endometrial cancer \\
\hline EGF & epidermal growth factor \\
\hline EGCG & Epigallocatechin gallate \\
\hline EMT & epithelial-mesenchymal transition \\
\hline ER & endoplasmic reticulum \\
\hline ERK1/2 & extracellular signal-regulated kinases \\
\hline GC & glucocorticoid \\
\hline GPER & G protein-coupled estrogen receptor \\
\hline HSC-1 & a human skin squamous carcinoma cell line \\
\hline IAA & sodium iodoacetate \\
\hline IP3R & inositol trisphosphate receptor \\
\hline IAA & sodium iodoacetate \\
\hline MAPK & mitogen-activated protein kinase \\
\hline MCU & mitochondrial calcium uniporter \\
\hline mTOR & mechanistic target of rapamycin \\
\hline NB & neuroblastoma \\
\hline NCS-1 & neuronal $\mathrm{Ca}^{2+}$ sensor 1 \\
\hline NHBE & normal human bronchial epithelial \\
\hline NSAID & non-steroidal anti-inflammatory drugs \\
\hline Orai1 & calcium release-activated calcium channel protein 1 \\
\hline PMCA & plasma membrane calcium ATPase \\
\hline PML & promyelocytic leukemia protein \\
\hline PTP & permeability transition pore \\
\hline RyR & ryanodine receptors \\
\hline SCID & severe combined immune deficiency syndrome \\
\hline SERCA & sarco/endoplasmic reticulum $\mathrm{Ca}^{2+}$-ATPase \\
\hline SK3 & small-conductance calcium-activated potassium channel \\
\hline SOC & store operated channel \\
\hline STIM1 & stromal interaction molecule 1 \\
\hline TGF $\beta$ & transforming growth factor beta \\
\hline $\mathrm{TM}$ & tamoxifen \\
\hline $\mathrm{TF}$ & transcription factor \\
\hline TSA & trichostatin A \\
\hline TRPC1 & transient receptor potential channel 1 \\
\hline TRPV1 & transient receptor potential vanilloid 1 \\
\hline V-ATPase & vacuolar-type $\mathrm{H}^{+}$-ATPase \\
\hline
\end{tabular}


VDAC1 voltage-dependent anion channel

VGCC voltage gated calcium channel

VGEF vascular endothelial growth factor

VOC voltage operated calcium channel

2-APB 2-Aminoethoxydiphenyl borate

5-FU 5-Fluorouracil

\section{References}

1. Bootman, M.D.; Rietdorf, K.; Hardy, H.; Dautova, Y.; Corps, E.; Pierro, C.; Stapleton, E.; Kang, E.; Proudfoot, D. Calcium Signalling and Regulation of Cell Function. In eLS; John Wiley \& Sons, Ltd.: Hoboken, NJ, USA, 2012. [CrossRef]

2. Munaron, L.; Antoniotti, S.; Lovisolo, D. Intracellular calcium signals and control of cell proliferation: How many mechanisms? J. Cell. Mol. Med. 2004, 8, 161-168. [CrossRef] [PubMed]

3. Miyazaki, S. Calcium signalling during mammalian fertilization. Ciba Found. Symp. 1995, 188, 235-247; discussion 247-251. [PubMed]

4. Bezprozvanny, I. Calcium signaling and neurodegenerative diseases. Trends Mol. Med. 2009, 15, 89-100. [CrossRef] [PubMed]

5. Gilon, P.; Chae, H.-Y.; Rutter, G.A.; Ravier, M.A. Calcium signaling in pancreatic $\beta$-cells in health and in Type 2 diabetes. Cell Calcium 2014, 56, 340-361. [CrossRef] [PubMed]

6. Luo, M.; Anderson Mark, E. Mechanisms of Altered Ca ${ }^{2+}$ Handling in Heart Failure. Circ. Res. 2013, 113, 690-708. [CrossRef]

7. Cui, C.; Merritt, R.; Fu, L.; Pan, Z. Targeting calcium signaling in cancer therapy. Acta Pharm. Sin. B 2017, 7, 3-17. [CrossRef]

8. Wang, W.; Ren, Y.; Wang, L.; Zhao, W.; Dong, X.; Pan, J.; Gao, H.; Tian, Y. Orai1 and Stim1 Mediate the Majority of Store-Operated Calcium Entry in Multiple Myeloma and Have Strong Implications for Adverse Prognosis. Cell. Physiol. Biochem. 2018, 48, 2273-2285. [CrossRef]

9. Berridge, M.J.; Lipp, P.; Bootman, M.D. The versatility and universality of calcium signalling. Nat. Rev. Mol. Cell Biol. 2000, 1, 11-21. [CrossRef]

10. Bagur, R.; Hajnóczky, G. Intracellular $\mathrm{Ca}(2+)$ Sensing: Its Role in Calcium Homeostasis and Signaling. Mol. Cell 2017, 66, 780-788. [CrossRef]

11. Reddish, F.N.; Miller, C.L.; Gorkhali, R.; Yang, J.J. Calcium Dynamics Mediated by the Endoplasmic/Sarcoplasmic Reticulum and Related Diseases. Int. J. Mol. Sci. 2017, 18, 1024. [CrossRef]

12. Williams, J.A.; Hou, Y.; Ni, H.-M.; Ding, W.-X. Role of intracellular calcium in proteasome inhibitor-induced endoplasmic reticulum stress, autophagy, and cell death. Pharm. Res. 2013, 30, 2279-2289. [CrossRef] [PubMed]

13. Rizzuto, R.; Marchi, S.; Bonora, M.; Aguiari, P.; Bononi, A.; De Stefani, D.; Giorgi, C.; Leo, S.; Rimessi, A.; Siviero, R.; et al. $\mathrm{Ca}(2+)$ transfer from the ER to mitochondria: When, how and why. Biochim. Biophys. Acta 2009, 1787, 1342-1351. [CrossRef] [PubMed]

14. Yáñez, M.; Gil-Longo, J.; Campos-Toimil, M. Calcium Binding Proteins. In Calcium Signaling; Islam, M.S., Ed.; Springer: Dordrecht, The Netherlands, 2012; pp. 461-482.

15. Bading, H. Nuclear calcium signalling in the regulation of brain function. Nat. Rev. Neurosci. 2013, 14, 593-608. [CrossRef]

16. Resende, R.R.; Andrade, L.M.; Oliveira, A.G.; Guimarães, E.S.; Guatimosim, S.; Leite, M.F. Nucleoplasmic calcium signaling and cell proliferation: Calcium signaling in the nucleus. Cell Commun. Signal. 2013, 11, 14. [CrossRef] [PubMed]

17. Leite, M.F.; Thrower, E.C.; Echevarria, W.; Koulen, P.; Hirata, K.; Bennett, A.M.; Ehrlich, B.E.; Nathanson, M.H. Nuclear and cytosolic calcium are regulated independently. Proc. Natl. Acad. Sci. USA 2003, 100, 2975-2980. [CrossRef] [PubMed]

18. Allbritton, N.L.; Oancea, E.; Kuhn, M.A.; Meyer, T. Source of nuclear calcium signals. Proc. Natl. Acad. Sci. USA 1994, 91, 12458-12462. [CrossRef]

19. Echevarria, W.; Leite, M.F.; Guerra, M.T.; Zipfel, W.R.; Nathanson, M.H. Regulation of calcium signals in the nucleus by a nucleoplasmic reticulum. Nat. Cell Biol. 2003, 5, 440-446. [CrossRef] 
20. Ikura, M.; Osawa, M.; Ames, J.B. The role of calcium-binding proteins in the control of transcription: Structure to function. BioEssays 2002, 24, 625-636. [CrossRef]

21. Hiraoki, T.; Vogel, H.J. Structure and Function of Calcium-Binding Proteins. J. Cardiovasc. Pharmacol. 1987, 10, S14-S31. [CrossRef]

22. Prevarskaya, N.; Skryma, R.; Bidaux, G.; Flourakis, M.; Shuba, Y. Ion channels in death and differentiation of prostate cancer cells. Cell Death Differ. 2007, 14, 1295. [CrossRef]

23. Florea, A.M.; Busselberg, D. Anti-cancer drugs interfere with intracellular calcium signaling. Neurotoxicology 2009, 30, 803-810. [CrossRef] [PubMed]

24. Florea, A.-M.; Splettstoesser, F.; Büsselberg, D. Arsenic trioxide $\left(\mathrm{As}_{2} \mathrm{O}_{3}\right)$ induced calcium signals and cytotoxicity in two human cell lines: SY-5Y neuroblastoma and 293 embryonic kidney (HEK). Toxicol. Appl. Pharmacol. 2007, 220, 292-301. [CrossRef] [PubMed]

25. Varghese, E.; Busselberg, D. Auranofin, an anti-rheumatic gold compound, modulates apoptosis by elevating the intracellular calcium concentration $\left(\left[\mathrm{Ca}^{2+}\right]_{\mathrm{i}}\right)$ in mcf-7 breast cancer cells. Cancers 2014, 6, 2243-2258. [CrossRef] [PubMed]

26. Capiod, T.; Shuba, Y.; Skryma, R.; Prevarskaya, N. Calcium signalling and cancer cell growth. In Calcium Signalling and Disease; Springer: Dordrecht, The The Netherlands, 2007; Volume 45, pp. 405-427.

27. Xu, M.; Seas, A.; Kiyani, M.; Ji, K.S.Y.; Bell, H.N. A temporal examination of calcium signaling in cancerfrom tumorigenesis, to immune evasion, and metastasis. Cell Biosci. 2018, 8, 25. [CrossRef]

28. Boynton, A.L.; Whitfield, J.F.; Isaacs, R.J.; Morton, H.J. Control of 3 T3 cell proliferation by calcium. In Vitro 1974, 10, 12-17. [CrossRef] [PubMed]

29. Pinto, M.C.X.; Kihara, A.H.; Goulart, V.A.M.; Tonelli, F.M.P.; Gomes, K.N.; Ulrich, H.; Resende, R.R. Calcium signaling and cell proliferation. Cell. Signal. 2015, 27, 2139-2149. [CrossRef] [PubMed]

30. Borowiec, A.-S.; Bidaux, G.; Pigat, N.; Goffin, V.; Bernichtein, S.; Capiod, T. Calcium channels, external calcium concentration and cell proliferation. Eur. J. Pharmacol. 2014, 739, 19-25. [CrossRef] [PubMed]

31. Splettstoesser, F.; Florea, A.M.; Busselberg, D. IP(3) receptor antagonist, 2-APB, attenuates cisplatin induced $\mathrm{Ca}^{2+}$-influx in HeLa-S3 cells and prevents activation of calpain and induction of apoptosis. Br. J. Pharmacol. 2007, 151, 1176-1186. [CrossRef]

32. Capiod, T. Extracellular Calcium Has Multiple Targets to Control Cell Proliferation. In Calcium Entry Pathways in Non-Excitable Cells; Rosado, J.A., Ed.; Springer International Publishing: Cham, Switzerland, 2016; pp. 133-156.

33. Flucher, B.E.; Tuluc, P. How and why are calcium currents curtailed in the skeletal muscle voltage-gated calcium channels? J. Physiol. 2017, 595, 1451-1463. [CrossRef]

34. Phan, N.N.; Wang, C.-Y.; Chen, C.-F.; Sun, Z.; Lai, M.-D.; Lin, Y.-C. Voltage-gated calcium channels: Novel targets for cancer therapy. Oncol. Lett. 2017, 14, 2059-2074. [CrossRef]

35. Hao, J.; Bao, X.; Jin, B.; Wang, X.; Mao, Z.; Li, X.; Wei, L.; Shen, D.; Wang, J.-L. Ca ${ }^{2+}$ channel subunit $\alpha$ $1 \mathrm{D}$ promotes proliferation and migration of endometrial cancer cells mediated by $17 \beta$-estradiol via the $G$ protein-coupled estrogen receptor. FASEB J. 2015, 29, 2883-2893. [CrossRef] [PubMed]

36. Ji, Y.; Han, Z.; Shao, L.; Zhao, Y. Ultrasound-targeted microbubble destruction of calcium channel subunit $\alpha$ 1D siRNA inhibits breast cancer via G protein-coupled receptor 30. Oncol. Rep. 2016, 36, 1886-1892. [CrossRef] [PubMed]

37. Chen, R.; Zeng, X.; Zhang, R.; Huang, J.; Kuang, X.; Yang, J.; Liu, J.; Tawfik, O.; Brantley Thrasher, J.; Li, B. Cav1.3 channel $\alpha 1 \mathrm{D}$ protein is overexpressed and modulates androgen receptor transactivation in prostate cancers. Urol. Oncol. Semin. Orig. Investig. 2014, 32, 524-536. [CrossRef] [PubMed]

38. Triggle, D.J. The Physiological and Pharmacological Significance of Cardiovascular T-Type, Voltage-gated Calcium Channels. Am. J. Hypertens. 1998, 11, 80S-87S. [CrossRef]

39. Antal, L.; Martin-Caraballo, M. T-type Calcium Channels in Cancer. Cancers 2019, 11, 134. [CrossRef]

40. Dziegielewska, B.; Gray, L.S.; Dziegielewski, J. T-type calcium channels blockers as new tools in cancer therapies. Pflügers Archiv 2014, 466, 801-810. [CrossRef] [PubMed]

41. Ohkubo, T.; Yamazaki, J. T-type voltage-activated calcium channel Cav3.1, but not Cav3.2, is involved in the inhibition of proliferation and apoptosis in MCF-7 human breast cancer cells. Int. J. Oncol. 2012, 41, 267-275. [CrossRef]

42. James, A.D.; Chan, A.; Erice, O.; Siriwardena, A.K.; Bruce, J.I.E. Glycolytic ATP fuels the plasma membrane calcium pump critical for pancreatic cancer cell survival. J. Biol. Chem. 2013, 288, 36007-36019. [CrossRef] 
43. Prakriya, M.; Lewis, R.S. Store-Operated Calcium Channels. Physiol. Rev. 2015, 95, 1383-1436. [CrossRef]

44. Giachini, F.R.; Lima, V.V.; Hannan, J.L.; Carneiro, F.S.; Webb, R.C.; Tostes, R.C. STIM1/Orai1-mediated store-operated $\mathrm{Ca}^{2+}$ entry: The tip of the iceberg. Braz. J. Med. Biol. Res. 2011, 44, 1080-1087. [CrossRef]

45. Lipskaia, L.; Hulot, J.-S.; Lompré, A.-M. Role of sarco/endoplasmic reticulum calcium content and calcium ATPase activity in the control of cell growth and proliferation. Pflügers Archiv 2009, 457, 673-685. [CrossRef] [PubMed]

46. Emeriau, N.; de Clippele, M.; Gailly, P.; Tajeddine, N. Store operated calcium entry is altered by the inhibition of receptors tyrosine kinase. Oncotarget 2018, 9, 16059-16073. [CrossRef] [PubMed]

47. Zhang, S.; Miao, Y.; Zheng, X.; Gong, Y.; Zhang, J.; Zou, F.; Cai, C. STIM1 and STIM2 differently regulate endogenous $\mathrm{Ca} 2+$ entry and promote TGF- $\beta$-induced EMT in breast cancer cells. Biochem. Biophys. Res. Commun. 2017, 488, 74-80. [CrossRef] [PubMed]

48. McAndrew, D.; Grice, D.M.; Peters, A.A.; Davis, F.M.; Stewart, T.; Rice, M.; Smart, C.E.; Brown, M.A.; Kenny, P.A.; Roberts-Thomson, S.J.; et al. ORAI1-Mediated Calcium Influx in Lactation and in Breast Cancer. Mol. Cancer Ther. 2011, 10, 448-460. [CrossRef] [PubMed]

49. Faouzi, M.; Hague, F.; Potier, M.; Ahidouch, A.; Sevestre, H.; Ouadid-Ahidouch, H. Down-regulation of Orai3 arrests cell-cycle progression and induces apoptosis in breast cancer cells but not in normal breast epithelial cells. J. Cell. Physiol. 2011, 226, 542-551. [CrossRef] [PubMed]

50. Weiss, H.; Amberger, A.; Widschwendter, M.; Margreiter, R.; Öfner, D.; Dietl, P. Inhibition of store-operated calcium entry contributes to the anti-proliferative effect of non-steroidal anti-inflammatory drugs in human colon cancer cells. Int. J. Cancer 2001, 92, 877-882. [CrossRef] [PubMed]

51. Mo, P.; Yang, S. The store-operated calcium channels in cancer metastasis: From cell migration, invasion to metastatic colonization. Front. Biosci. 2018, 23, 1241-1256.

52. Yang, Z.; Pan, L.; Liu, S.; Li, F.; Lv, W.; Shu, Y.; Dong, P. Inhibition of stromal-interacting molecule 1-mediated store-operated $\mathrm{Ca}(2+)$ entry as a novel strategy for the treatment of acquired imatinib-resistant gastrointestinal stromal tumors. Cancer Sci. 2018, 109, 2792-2800. [CrossRef]

53. Yang, N.; Tang, Y.; Wang, F.; Zhang, H.; Xu, D.; Shen, Y.; Sun, S.; Yang, G. Blockade of store-operated $\mathrm{Ca}^{2+}$ entry inhibits hepatocarcinoma cell migration and invasion by regulating focal adhesion turnover. Cancer Lett. 2013, 330, 163-169. [CrossRef]

54. Primeau, J.O.; Armanious, G.P.; Fisher, M.L.E.; Young, H.S. The SarcoEndoplasmic Reticulum Calcium ATPase. In Membrane Protein Complexes: Structure and Function; Harris, J.R., Boekema, E.J., Eds.; Springer: Singapore, 2018; pp. 229-258.

55. Fan, L.; Li, A.; Li, W.; Cai, P.; Yang, B.; Zhang, M.; Gu, Y.; Shu, Y.; Sun, Y.; Shen, Y.; et al. Novel role of Sarco/endoplasmic reticulum calcium ATPase 2 in development of colorectal cancer and its regulation by F36, a curcumin analog. Biomed. Pharmacother. 2014, 68, 1141-1148. [CrossRef]

56. Legrand, G.; Humez, S.; Slomianny, C.; Dewailly, E.; Vanden Abeele, F.; Mariot, P.; Wuytack, F.; Prevarskaya, N. $\mathrm{Ca}^{2+}$ pools and cell growth. Evidence for sarcoendoplasmic Ca2+-ATPases 2B involvement in human prostate cancer cell growth control. J. Biol. Chem. 2001, 276, 47608-47614. [CrossRef] [PubMed]

57. Bergner, A.; Kellner, J.; Tufman, A.; Huber, R.M. Endoplasmic reticulum $\mathrm{Ca}^{2+}$-homeostasis is altered in small and non-small cell lung cancer cell lines. J. Exp. Clin. Cancer Res. 2009, 28, 25. [CrossRef] [PubMed]

58. Rizzuto, R.; Pinton, P.; Carrington, W.; Fay, F.S.; Fogarty, K.E.; Lifshitz, L.M.; Tuft, R.A.; Pozzan, T. Close Contacts with the Endoplasmic Reticulum as Determinants of Mitochondrial Ca2+ Responses. Science 1998, 280, 1763-1766. [CrossRef] [PubMed]

59. Ivanova, H.; Kerkhofs, M.; La Rovere, R.M.; Bultynck, G. Endoplasmic Reticulum-Mitochondrial Ca(2+) Fluxes Underlying Cancer Cell Survival. Front. Oncol. 2017, 7, 70. [CrossRef] [PubMed]

60. Tarasov, A.I.; Griffiths, E.J.; Rutter, G.A. Regulation of ATP production by mitochondrial Ca(2+). Cell Calcium 2012, 52, 28-35. [CrossRef] [PubMed]

61. Luongo, T.S.; Lambert, J.P.; Gross, P.; Nwokedi, M.; Lombardi, A.A.; Shanmughapriya, S.; Carpenter, A.C.; Kolmetzky, D.; Gao, E.; van Berlo, J.H.; et al. The mitochondrial $\mathrm{Na}(+) / \mathrm{Ca}(2+)$ exchanger is essential for $\mathrm{Ca}(2+)$ homeostasis and viability. Nature 2017, 545, 93-97. [CrossRef]

62. Marchi, S.; Vitto, V.A.M.; Danese, A.; Wieckowski, M.R.; Giorgi, C.; Pinton, P. Mitochondrial calcium uniporter complex modulation in cancerogenesis. Cell Cycle 2019, 18, 1068-1083. [CrossRef]

63. Romero-Garcia, S.; Prado-Garcia, H. Mitochondrial calcium: Transport and modulation of cellular processes in homeostasis and cancer (Review). Int. J. Oncol. 2019, 54, 1155-1167. [CrossRef] 
64. Rathore, R.; McCallum, J.E.; Varghese, E.; Florea, A.M.; Busselberg, D. Overcoming chemotherapy drug resistance by targeting inhibitors of apoptosis proteins (IAPs). Apoptosis 2017, 22, 898-919. [CrossRef]

65. Vervliet, T.; Parys, J.B.; Bultynck, G. Bcl-2 proteins and calcium signaling: Complexity beneath the surface. Oncogene 2016, 35, 5079. [CrossRef]

66. Shoshan-Barmatz, V.; Ben-Hail, D.; Admoni, L.; Krelin, Y.; Tripathi, S.S. The mitochondrial voltage-dependent anion channel 1 in tumor cells. Biochim. Biophys. Acta Biomembr. 2015, 1848, 2547-2575. [CrossRef] [PubMed]

67. Weisthal, S.; Keinan, N.; Ben-Hail, D.; Arif, T.; Shoshan-Barmatz, V. Ca ${ }^{2+}$-mediated regulation of VDAC1 expression levels is associated with cell death induction. Biochim. Biophys. Acta Mol. Cell Res. 2014, 1843, 2270-2281. [CrossRef] [PubMed]

68. Wertz, I.E.; Dixit, V.M. Characterization of Calcium Release-activated Apoptosis of LNCaP Prostate Cancer Cells. J. Biol. Chem. 2000, 275, 11470-11477. [CrossRef] [PubMed]

69. Sehgal, P.; Szalai, P.; Olesen, C.; Praetorius, H.A.; Nissen, P.; Christensen, S.B.; Engedal, N.; Møller, J.V. Inhibition of the sarco/endoplasmic reticulum (ER) Ca(2+)-ATPase by thapsigargin analogs induces cell death via $\mathrm{ER} \mathrm{Ca(2+)} \mathrm{depletion} \mathrm{and} \mathrm{the} \mathrm{unfolded} \mathrm{protein} \mathrm{response.} \mathrm{J.} \mathrm{Biol.} \mathrm{Chem.} \mathrm{2017,} \mathrm{292,} \mathrm{19656-19673.}$ [CrossRef] [PubMed]

70. Stewart, T.A.; Yapa, K.T.D.S.; Monteith, G.R. Altered calcium signaling in cancer cells. Biochim. Biophys. Acta Biomembr. 2015, 1848, 2502-2511. [CrossRef] [PubMed]

71. Günes, D.A.; Florea, A.-M.; Splettstoesser, F.; Büsselberg, D. Co-application of arsenic trioxide (As2O3) and cisplatin (CDDP) on human SY-5Y neuroblastoma cells has differential effects on the intracellular calcium concentration $\left(\left[\mathrm{Ca}^{2+}\right]_{\mathrm{i}}\right)$ and cytotoxicity. Neurotoxicology 2009, 30, 194-202. [CrossRef] [PubMed]

72. Al-Taweel, N.; Varghese, E.; Florea, A.-M.; Büsselberg, D. Cisplatin (CDDP) triggers cell death of MCF-7 cells following disruption of intracellular calcium Ca2+ homeostasis. J. Toxicol. Sci. 2014, 39, 765-774. [CrossRef]

73. Shen, L.; Wen, N.; Xia, M.; Zhang, Y.U.; Liu, W.; Xu, Y.E.; Sun, L. Calcium efflux from the endoplasmic reticulum regulates cisplatin-induced apoptosis in human cervical cancer HeLa cells. Oncol. Lett. 2016, 11, 2411-2419. [CrossRef]

74. Can, G.; Akpinar, B.; Baran, Y.; Zhivotovsky, B.; Olsson, M. 5-Fluorouracil signaling through a calcium-calmodulin-dependent pathway is required for p53 activation and apoptosis in colon carcinoma cells. Oncogene 2012, 32, 4529. [CrossRef]

75. Deveci, H.A.; Nazıroğlu, M.; Nur, G. 5-Fluorouracil-induced mitochondrial oxidative cytotoxicity and apoptosis are increased in MCF-7 human breast cancer cells by TRPV1 channel activation but not Hypericum perforatum treatment. Mol. Cell. Biochem. 2018, 439, 189-198. [CrossRef]

76. Kerkhofs, M.; Bittremieux, M.; Morciano, G.; Giorgi, C.; Pinton, P.; Parys, J.B.; Bultynck, G. Emerging molecular mechanisms in chemotherapy: $\mathrm{Ca}^{2+}$ signaling at the mitochondria-associated endoplasmic reticulum membranes. Cell Death Dis. 2018, 9, 334. [CrossRef] [PubMed]

77. Missiroli, S.; Bonora, M.; Patergnani, S.; Poletti, F.; Perrone, M.; Gafà, R.; Magri, E.; Raimondi, A.; Lanza, G.; Tacchetti, C.; et al. PML at Mitochondria-Associated Membranes Is Critical for the Repression of Autophagy and Cancer Development. Cell Rep. 2016, 16, 2415-2427. [CrossRef] [PubMed]

78. Iwama, K.; Nakajo, S.; Aiuchi, T.; Nakaya, K. Apoptosis induced by arsenic trioxide in leukemia U937 cells is dependent on activation of p38, inactivation of ERK and the Ca2+-dependent production of superoxide. Int. J. Cancer 2001, 92, 518-526. [CrossRef] [PubMed]

79. Abdoul-Azize, S.; Buquet, C.; Li, H.; Picquenot, J.-M.; Vannier, J.-P. Integration of $\mathrm{Ca}^{2+}$ signaling regulates the breast tumor cell response to simvastatin and doxorubicin. Oncogene 2018, 37, 4979-4993. [CrossRef] [PubMed]

80. Blanc, M.C.; Holton, M.; Baggott, R.R.; Roux-Soro, S.C.; Armesilla, A.L.; Oceandy, D.; Cartwright, E.J.; Neyses, L.; Mohamed, T.M.A.; Brown, S.; et al. Disruption of the interaction between PMCA2 and calcineurin triggers apoptosis and enhances paclitaxel-induced cytotoxicity in breast cancer cells. Carcinogenesis 2012, 33, 2362-2368. [CrossRef]

81. Pan, Z.; Avila, A.; Gollahon, L. Paclitaxel induces apoptosis in breast cancer cells through different calcium-regulating mechanisms depending on external calcium conditions. Int. J. Mol. Sci. 2014, 15, 2672-2694. [CrossRef] [PubMed]

82. Winter, E.; Chiaradia, L.D.; Silva, A.H.; Nunes, R.J.; Yunes, R.A.; Creczynski-Pasa, T.B. Involvement of extrinsic and intrinsic apoptotic pathways together with endoplasmic reticulum stress in cell death induced 
by naphthylchalcones in a leukemic cell line: Advantages of multi-target action. Toxicol. In Vitro 2014, 28, 769-777. [CrossRef] [PubMed]

83. van Ginkel, P.R.; Yan, M.B.; Bhattacharya, S.; Polans, A.S.; Kenealey, J.D. Natural products induce a G protein-mediated calcium pathway activating p53 in cancer cells. Toxicol. Appl. Pharmacol. 2015, 288, 453-462. [CrossRef]

84. Varghese, E.; Samuel, S.M.; Abotaleb, M.; Cheema, S.; Mamtani, R.; Büsselberg, D. The "Yin and Yang" of Natural Compounds in Anticancer Therapy of Triple-Negative Breast Cancers. Cancers 2018, 10, 346. [CrossRef]

85. Madreiter-Sokolowski, C.T.; Gottschalk, B.; Parichatikanond, W.; Eroglu, E.; Klec, C.; Waldeck-Weiermair, M.; Malli, R.; Graier, W.F. Resveratrol Specifically Kills Cancer Cells by a Devastating Increase in the Ca2+ Coupling Between the Greatly Tethered Endoplasmic Reticulum and Mitochondria. Cell. Physiol. Biochem. 2016, 39, 1404-1420. [CrossRef]

86. Wong, V.K.; Li, T.; Law, B.Y.; Ma, E.D.; Yip, N.C.; Michelangeli, F.; Law, C.K.; Zhang, M.M.; Lam, K.Y.; Chan, P.L.; et al. Saikosaponin-d, a novel SERCA inhibitor, induces autophagic cell death in apoptosis-defective cells. Cell Death Dis. 2013, 4, e720. [CrossRef] [PubMed]

87. Florea, A.M.; Varghese, E.; McCallum, J.E.; Mahgoub, S.; Helmy, I.; Varghese, S.; Gopinath, N.; Sass, S.; Theis, F.J.; Reifenberger, G.; et al. Calcium-regulatory proteins as modulators of chemotherapy in human neuroblastoma. Oncotarget 2017, 8, 22876-22893. [CrossRef] [PubMed]

88. Zhang, W.; Couldwell, W.T.; Song, H.; Takano, T.; Lin, J.H.C.; Nedergaard, M. Tamoxifen-induced Enhancement of Calcium Signaling in Glioma and MCF-7 Breast Cancer Cells. Cancer Res. 2000, 60, 5395. [PubMed]

89. Jan, C.-R.; Cheng, J.-S.; Chou, K.-J.; Wang, S.-P.; Lee, K.C.; Tang, K.-Y.; Tseng, L.-L.; Chiang, H.-T. Dual Effect of Tamoxifen, an Anti-Breast-Cancer Drug, on Intracellular Ca2+ and Cytotoxicity in Intact Cells. Toxicol. Appl. Pharmacol. 2000, 168, 58-63. [CrossRef] [PubMed]

90. Lu, Y.-C.; Jiann, B.-P.; Chang, H.-T.; Huang, J.-K.; Chen, W.-C.; Su, W.; Jan, C.-R. Effect of the Anti-Breast Cancer Drug Tamoxifen on $\mathrm{Ca}^{2+}$ Movement in Human Osteosarcoma Cells. Pharmacol. Toxicol. 2002, 91, 34-39. [CrossRef] [PubMed]

91. Chang, H.-T.; Huang, J.-K.; Wang, J.-L.; Cheng, J.-S.; Lee, K.-C.; Lo, Y.-K.; Liu, C.-P.; Chou, K.-J.; Chen, W.-C.; $\mathrm{Su}, \mathrm{W}$; et al. Tamoxifen-Induced Increases in Cytoplasmic Free $\mathrm{Ca}^{2+}$ Levels in Human Breast Cancer Cells. Breast Cancer Res. Treat. 2002, 71, 125-131. [CrossRef] [PubMed]

92. Hasegawa, G.; Akatsuka, K.; Nakashima, Y.; Yokoe, Y.; Higo, N.; Shimonaka, M. Tamoxifen inhibits the proliferation of non-melanoma skin cancer cells by increasing intracellular calcium concentration. Int. J. Oncol. 2018, 53, 2157-2166. [CrossRef]

93. Meneses-Morales, I.; Izquierdo-Torres, E.; Flores-Peredo, L.; Rodríguez, G.; Hernández-Oliveras, A.; Zarain-Herzberg, Á. Epigenetic regulation of the human ATP2A3 gene promoter in gastric and colon cancer cell lines. Mol. Carcinog. 2019, 58, 887-897. [CrossRef]

94. Raynal, N.J.M.; Lee, J.T.; Wang, Y.; Beaudry, A.; Madireddi, P.; Garriga, J.; Malouf, G.G.; Dumont, S.; Dettman, E.J.; Gharibyan, V.; et al. Targeting Calcium Signaling Induces Epigenetic Reactivation of Tumor Suppressor Genes in Cancer. Cancer Res. 2016, 76, 1494-1505. [CrossRef]

95. Kim, J.-A.; Kang, Y.S.; Jung, M.-W.; Lee, S.H.; Lee, Y.S. Involvement of $\mathrm{Ca}^{2+}$ influx in the mechanism of tamoxifen-induced apoptosis in HepG2 human hepatoblastoma cells. Cancer Lett. 1999, 147, 115-123. [CrossRef]

96. Tomaszewski, A.; Büsselberg, D. Cisplatin modulates voltage gated channel currents of dorsal root ganglion neurons of rats. Neurotoxicology 2007, 28, 49-58. [CrossRef] [PubMed]

97. Gualdani, R.; de Clippele, M.; Ratbi, I.; Gailly, P.; Tajeddine, N. Store-Operated Calcium Entry Contributes to Cisplatin-Induced Cell Death in Non-Small Cell Lung Carcinoma. Cancers 2019, 11, 430. [CrossRef] [PubMed]

98. Satheesh, N.J.; Büsselberg, D. The role of intracellular calcium for the development and treatment of neuroblastoma. Cancers 2015, 7, 823-848. [CrossRef] [PubMed]

99. Zhao, C.; Lu, E.; Hu, X.; Cheng, H.; Zhang, J.-A.; Zhu, X. S100A9 regulates cisplatin chemosensitivity of squamous cervical cancer cells and related mechanism. Cancer Manag. Res. 2018, 10, 3753-3764. [CrossRef] [PubMed] 
100. Pelzl, L.; Hosseinzadeh, Z.; Alzoubi, K.; Al-Maghout, T.; Schmidt, S.; Stournaras, C.; Lang, F. Impact of $\mathrm{Na}+/ \mathrm{Ca}^{2+}$ Exchangers on Therapy Resistance of Ovary Carcinoma Cells. Cell. Physiol. Biochem. 2015, 37, 1857-1868. [CrossRef] [PubMed]

101. Schulze, C.; McGowan, M.; Jordt, S.-E.; Ehrlich, B.E. Prolonged oxaliplatin exposure alters intracellular calcium signaling: A new mechanism to explain oxaliplatin-associated peripheral neuropathy. Clin. Colorectal Cancer 2011, 10, 126-133. [CrossRef] [PubMed]

102. Muscella, A.; Vetrugno, C.; Fanizzi, F.P.; Manca, C.; De Pascali, S.A.; Marsigliante, S. A new platinum(II) compound anticancer drug candidate with selective cytotoxicity for breast cancer cells. Cell Death Dis. 2013, 4, e796. [CrossRef]

103. Antman, K.H. Introduction: The history of arsenic trioxide in cancer therapy. Oncologist 2001, 6 (Suppl. 2), 1-2. [CrossRef]

104. Liu, L.Z.; Jiang, Y.; Carpenter, R.L.; Jing, Y.; Peiper, S.C.; Jiang, B.H. Role and mechanism of arsenic in regulating angiogenesis. PLOS ONE 2011, 6, e20858. [CrossRef]

105. Park, W.H.; Seol, J.G.; Kim, E.S.; Hyun, J.M.; Jung, C.W.; Lee, C.C.; Kim, B.K.; Lee, Y.Y. Arsenic Trioxide-mediated Growth Inhibition in MC/CAR Myeloma Cells via Cell Cycle Arrest in Association with Induction of Cyclin-dependent Kinase Inhibitor, p21, and Apoptosis. Cancer Res. 2000, 60, 3065-3071.

106. Jing, Y.; Dai, J.; Chalmers-Redman, R.M.E.; Tatton, W.G.; Waxman, S. Arsenic Trioxide Selectively Induces Acute Promyelocytic Leukemia Cell Apoptosis Via a Hydrogen Peroxide-Dependent Pathway. Blood 1999, 94 , 2102-2111. [PubMed]

107. Nguyen, T.T.T.; Lim, Y.J.; Fan, M.H.M.; Jackson, R.A.; Lim, K.K.; Ang, W.H.; Ban, K.H.K.; Chen, E.S. Calcium modulation of doxorubicin cytotoxicity in yeast and human cells. Genes Cells 2016, 21, 226-240. [CrossRef] [PubMed]

108. Boehmerle, W.; Splittgerber, U.; Lazarus, M.B.; McKenzie, K.M.; Johnston, D.G.; Austin, D.J.; Ehrlich, B.E. Paclitaxel induces calcium oscillations via an inositol 1,4,5-trisphosphate receptor and neuronal calcium sensor 1-dependent mechanism. Proc. Natl. Acad. Sci. USA 2006, 103, 18356-18361. [CrossRef] [PubMed]

109. Greenstein, S.; Ghias, K.; Krett, N.L.; Rosen, S.T. Mechanisms of Glucocorticoid-mediated Apoptosis in Hematological Malignancies. Clin. Cancer Res. 2002, 8, 1681-1694. [PubMed]

110. Abdoul-Azize, S.; Dubus, I.; Vannier, J.-P. Improvement of dexamethasone sensitivity by chelation of intracellular Ca2+ in pediatric acute lymphoblastic leukemia cells through the prosurvival kinase ERK1/2 deactivation. Oncotarget 2017, 8, 27339-27352. [CrossRef] [PubMed]

111. Sareen, D.; Darjatmoko, S.R.; Albert, D.M.; Polans, A.S. Mitochondria, calcium, and calpain are key mediators of resveratrol-induced apoptosis in breast cancer. Mol. Pharmacol. 2007, 72, 1466-1475. [CrossRef] [PubMed]

112. Obakan, P.; Barrero, C.; Coker-Gurkan, A.; Arisan, E.D.; Merali, S.; Palavan-Unsal, N. SILAC-Based Mass Spectrometry Analysis Reveals That Epibrassinolide Induces Apoptosis via Activating Endoplasmic Reticulum Stress in Prostate Cancer Cells. PLoS ONE 2015, 10, e0135788. [CrossRef] [PubMed]

113. Park, S.; Lim, W.; You, S.; Song, G. Ameliorative effects of luteolin against endometriosis progression in vitro and in vivo. J. Nutr. Biochem. 2019, 67, 161-172. [CrossRef]

114. Park, S.; Lim, W.; Song, G. Delphinidin induces antiproliferation and apoptosis of endometrial cells by regulating cytosolic calcium levels and mitochondrial membrane potential depolarization. J. Cell. Biochem. 2019, 120, 5072-5084. [CrossRef]

115. Yu, F.S.; Yang, J.S.; Yu, C.S.; Lu, C.C.; Chiang, J.H.; Lin, C.W.; Chung, J.G. Safrole Induces Apoptosis in Human Oral Cancer HSC-3 Cells. J. Dent. Res. 2010, 90, 168-174. [CrossRef]

116. Wang, M.; Ruan, Y.; Chen, Q.; Li, S.; Wang, Q.; Cai, J. Curcumin induced HepG2 cell apoptosis-associated mitochondrial membrane potential and intracellular free Ca2+ concentration. Eur. J. Pharmacol. 2011, 650, 41-47. [CrossRef] [PubMed]

117. Liberti, M.V.; Locasale, J.W. The Warburg Effect: How Does it Benefit Cancer Cells? Trends Biochem. Sci. 2016, 41, 211-218. [CrossRef] [PubMed]

118. Samuel, S.M.; Varghese, E.; Varghese, S.; Busselberg, D. Challenges and perspectives in the treatment of diabetes associated breast cancer. Cancer Treat. Rev. 2018, 70, 98-111. [CrossRef] [PubMed]

119. Chakraborty, P.K.; Mustafi, S.B.; Xiong, X.; Dwivedi, S.K.D.; Nesin, V.; Saha, S.; Zhang, M.; Dhanasekaran, D.; Jayaraman, M.; Mannel, R.; et al. MICU1 drives glycolysis and chemoresistance in ovarian cancer. Nat. Commun. 2017, 8, 14634. [CrossRef] [PubMed] 
120. Chen, Z.; Tang, C.; Zhu, Y.; Xie, M.; He, D.; Pan, Q.; Zhang, P.; Hua, D.; Wang, T.; Jin, L.; et al. TrpC5 regulates differentiation through the $\mathrm{Ca}^{2+} / \mathrm{Wnt} 5$ a signalling pathway in colorectal cancer. Clin. Sci. 2017, 131, 227-237. [CrossRef] [PubMed]

121. Wang, T.; Ning, K.; Sun, X.; Zhang, C.; Jin, L.-F.; Hua, D. Glycolysis is essential for chemoresistance induced by transient receptor potential channel C5 in colorectal cancer. BMC Cancer 2018, 18, 207. [CrossRef]

122. Xie, J.; Wang, B.S.; Yu, D.H.; Lu, Q.; Ma, J.; Qi, H.; Fang, C.; Chen, H.Z. Dichloroacetate shifts the metabolism from glycolysis to glucose oxidation and exhibits synergistic growth inhibition with cisplatin in HeLa cells. Int. J. Oncol. 2011, 38, 409-417. [CrossRef]

123. Aoki, S.; Morita, M.; Hirao, T.; Yamaguchi, M.; Shiratori, R.; Kikuya, M.; Chibana, H.; Ito, K. Shift in energy metabolism caused by glucocorticoids enhances the effect of cytotoxic anti-cancer drugs against acute lymphoblastic leukemia cells. Oncotarget 2017, 8, 94271-94285. [CrossRef]

124. Freedman, R.A.; Tolaney, S.M. Efficacy and safety in older patient subsets in studies of endocrine monotherapy versus combination therapy in patients with HR+/HER2-advanced breast cancer: A review. Breast Cancer Res. Treat. 2018, 167, 607-614. [CrossRef]

125. Mason, R.P. Calcium channel blockers, apoptosis and cancer: Is there a biologic relationship? J. Am. Coll. Cardiol. 1999, 34, 1857-1866. [CrossRef]

126. Onoda, J.M.; Nelson, K.K.; Taylor, J.D.; Honn, K.V. Invivo Characterization of Combination Antitumor Chemotherapy with Calcium Channel Blockers and cis-Diamminedichloroplatinum(II). Cancer Res. 1989, 49, 2844-2850. [PubMed]

127. Pillozzi, S.; D’Amico, M.; Bartoli, G.; Gasparoli, L.; Petroni, G.; Crociani, O.; Marzo, T.; Guerriero, A.; Messori, L.; Severi, M.; et al. The combined activation of KCa3.1 and inhibition of Kv11.1/hERG1 currents contribute to overcome Cisplatin resistance in colorectal cancer cells. Br. J. Cancer 2017, 118, 200. [CrossRef] [PubMed]

128. Huang, J.-K.; Chou, C.-T.; Chang, H.-T.; Shu, S.-S.; Kuo, C.-C.; Tsai, J.-Y.; Liao, W.-C.; Wang, J.-L.; Lin, K.-L.; $\mathrm{Lu}, \mathrm{Y} .-\mathrm{C} . ;$ et al. Effect of thapsigargin on $\mathrm{Ca}^{2+}$ fluxes and viability in human prostate cancer cells. J. Recept. Signal Transduct. 2011, 31, 247-255. [CrossRef] [PubMed]

129. Ma, Z.; Fan, C.; Yang, Y.; Di, S.; Hu, W.; Li, T.; Zhu, Y.; Han, J.; Xin, Z.; Wu, G.; et al. Thapsigargin sensitizes human esophageal cancer to TRAIL-induced apoptosis via AMPK activation. Sci. Rep. 2016, 6, 35196. [CrossRef] [PubMed]

130. Jackisch, C.; Hahm, H.A.; Tombal, B.; McCloskey, D.; Butash, K.; Davidson, N.E.; Denmeade, S.R. Delayed Micromolar Elevation in Intracellular Calcium Precedes Induction of Apoptosis in Thapsigargin-treated Breast Cancer Cells. Clin. Cancer Res. 2000, 6, 2844-2850.

131. Thews, O.; Hummel, M.; Kelleher, D.K.; Lecher, B.; Vaupel, P. Nifedipine improves blood flow and oxygen supply, but not steady-state oxygenation of tumours in perfusion pressure-controlled isolated limb perfusion. Br. J. Cancer 2002, 87, 1462-1469. [CrossRef]

132. Wood, P.J.; Hirst, D.G. Modification of tumour response by calcium antagonists in the SCVII/St tumour implanted at two different sites. Int. J. Radiat. Biol. 1989, 56, 355-367. [CrossRef]

(C) 2019 by the authors. Licensee MDPI, Basel, Switzerland. This article is an open access article distributed under the terms and conditions of the Creative Commons Attribution (CC BY) license (http://creativecommons.org/licenses/by/4.0/). 